\title{
Susceptibility to Gully Erosion: Applying Random Forest (RF) and Frequency Ratio (FR) Approaches to a Small Catchment in Ethiopia
}

\author{
Selamawit Amare ${ }^{1,2, *}$, Eddy Langendoen ${ }^{3} \mathbb{C}$, Saskia Keesstra ${ }^{4,5}$, Martine van der Ploeg ${ }^{6} \mathbb{C D}_{\text {, }}$ \\ Habtamu Gelagay ${ }^{7}{ }^{(D}$, Hanibal Lemma ${ }^{2}$ and Sjoerd E. A. T. M. van der Zee ${ }^{1}{ }^{\mathbb{D}}$
}

1 Soil Physics and Land Management Group, Wageningen University and Research, 6700 AA Wageningen, The Netherlands; sjoerd.vanderzee@wur.nl

2 Faculty of Civil and Water Resources Engineering, Bahir Dar University, P.O. Box 26, Bahir Dar, Ethiopia; haniballemma@gmail.com

3 United States Department of Agriculture, Agricultural Research Service, National Sedimentation Laboratory, Oxford, MS 38655, USA; eddy.langendoen@usda.gov

4 Team Soil, Water and Land Use, Wageningen Environmental Research, 6708 PB Wageningen, The Netherlands; saskia.keesstra@wur.nl

5 Civil, Surveying and Environmental Engineering, The University of Newcastle, Callaghan 2308, Australia

6 Hydrology and Quantitative Water Management Group, Wageningen University and Research, 6700 AA Wageningen, The Netherlands; martine.vanderploeg@wur.nl

7 Geospatial Analytics Unit, Geospatial Information Institute, P.O. Box 597, Addis Ababa, Ethiopia; agsehagis@gmail.com

* Correspondence: selamawit.amare@wur.nl or selamawit.damtew@gmail.com

check for updates

Citation: Amare, S.; Langendoen, E.; Keesstra, S.; Ploeg, M.v.d.; Gelagay, H.; Lemma, H.; Zee, S.E.A.T.M.v.d. Susceptibility to Gully Erosion: Applying Random Forest (RF) and Frequency Ratio (FR) Approaches to a Small Catchment in Ethiopia. Water 2021, 13, 216. https://doi.org/ 10.3390/w13020216

Received: 20 October 2020

Accepted: 14 January 2021

Published: 18 January 2021

Publisher's Note: MDPI stays neutral with regard to jurisdictional claims in published maps and institutional affiliations.

Copyright: (c) 2021 by the authors. Licensee MDPI, Basel, Switzerland. This article is an open access article distributed under the terms and conditions of the Creative Commons Attribution (CC BY) license (https:/ / creativecommons.org/licenses/by/ $4.0 /)$.

\begin{abstract}
Soil erosion by gullies in Ethiopia is causing environmental and socioeconomic problems A sound soil and water management plan requires accurately predicted gully erosion hotspot areas. Hence, this study develops a gully erosion susceptibility map (GESM) using frequency ratio (FR) and random forest (RF) algorithms. A total of 56 gullies were surveyed, and their extents were derived by digitizing Google Earth imagery. Literature review and a multicollinearity test resulted in 14 environmental variables for the final analysis. Model prediction potential was evaluated using the area under the curve (AUC) method. Results showed that the best prediction accuracy using the FR and RF models was obtained by using the top four most important gully predictor factors: drainage density, elevation, land use, and groundwater table. The notion that the groundwater table is one of the most important gully predictor factors in Ethiopia is a novel and significant quantifiable finding and is critical to the design of effective watershed management plans. Results from separate variable importance analyses showed land cover for Nitisols and drainage density for Vertisols as leading factors determining gully locations. Factors such as texture, stream power index, convergence index, slope length, and plan and profile curvatures were found to have little significance for gully formation in the studied catchment.
\end{abstract}

Keywords: gully erosion mapping; Ethiopian highlands; Nitisols; Vertisols; soil type; groundwater table

\section{Introduction}

Although gullies occupy, on average, a small portion of a catchment $(<5 \%)$, land degradation due to gully erosion causes serious environmental and socioeconomic problems by affecting soil and land functions [1,2]. Gully erosion lowers the groundwater table [3] and increases the susceptibility of soils to drought, causing crop yield reduction [4]. Gullies also increase landscape connectivity by providing efficient paths for the transport of water, sediment, and other materials from the source to the sink [5,6]. This affects flooding and reservoir siltation [7]. Soil erosion studies worldwide have shown that sediment in rivers mainly originates from gully erosion [8]. In Ethiopia, severe gully erosion has been a major 
concern for both current and planned water management developments, which range from small-scale irrigation to large-scale hydroelectric dams [9-11]. Gully erosion in the Ethiopian highlands accounts for $28 \%$ of the soil loss in semiarid regions [12], whereas in the subhumid areas, it accounts for two orders of magnitude more soil loss than rill and inter-rill erosions [13].

In Ethiopia, the dominant causes of gully erosion have been investigated with regard to anthropogenic, morphologic, hydrologic, soil, and environmental aspects of a catchment. Land degradation by gullies has been associated with stagnation of agricultural technology and lack of agricultural intensification [14], increased traditional drainage ditches [15], drainage area, slope, and lithology [16], and elevated groundwater levels $[17,18]$. Furthermore, road construction can facilitate gully development by increasing its drainage area [19] and can cause up to one order of magnitude increase in gully head retreats [20]. Soil crack and pipes also aggravate gully erosion by allowing preferential water flow in the soil and increasing soil pore water pressure $[13,20]$.

Previous studies of gully erosion in Ethiopian highlands have been based on field monitoring [4,21-23] and combined field monitoring and interviews [7,13]. However, largescale field monitoring of gullies throughout a catchment is costly and labor-demanding. As a result, often, only a few parameters to understand the gully dynamics are measured, omitting other environmental factors that affect gully development.

In regions with developing economies, where resources are particularly limited to undertaking extensive field surveys, the use of prediction models can be effective for identifying areas susceptible to gully erosion and determining the most important drivers of gully erosion [24]. Prediction of gully-susceptible areas is essential for the appropriate planning of sustainable soil and water conservation measures $[24,25]$. Nowadays, statistical and machine-learning models have been successfully used to predict a variety of environmental properties across different fields, e.g., groundwater zoning [26], landslide hazard mapping [27-29], flood risk assessment [30], and gully-head susceptibility mapping [31]. Various techniques have been used to map gullies, such as entropy information value [32], multivariate adaptive regression splines [33], certainty factor and maximum entropy [34], frequency ratio [35,36], and random forest $[37,38]$.

Few studies in Ethiopia have predicted gully erosion by using topographical threshold factors such as the topographic wetness index (TWI) and the stream power index (SPI) $[39,40]$. The application of these thresholds is flawed mainly because streams and saturated-bottom lands are preferentially considered most vulnerable to gullies. This is particularly problematic when gullies are predominantly controlled by other factors (e.g., land use, soil type, and elevation). Since gully erosion is a function of various hydrological, geomorphic, and environmental factors [8], using more gully erosion factors in modeling would improve prediction accuracy.

Recently, FR and RF models were tested in several countries and gave very good gully prediction accuracies [41,42]. A recent field campaign in the Minzir catchment in the upper Blue Nile river basin (Ethiopia) [43] provides the necessary extra gully erosion factors for a more accurate gully-erosion susceptibility map (GESM). Therefore, the objective of this study is to develop this GESM using frequency ratio (FR) and random forest (RF) models for the Minzir catchment, Upper Blue Nile River Basin (Ethiopia). In addition to GESM, the RF model was also used to rank predictor factors based on their importance to gully erosion. Among the 16 selected factors, soil type and groundwater table (GWT) are new variables introduced to the models that have not been used in previous studies. Gully erosion predictor factors for the Nitisol- and Vertisol-dominated subcatchment were ranked separately. This distinction is based on the fact that the rate of gully erosion in Nitisol and Vertisol has been reported to be different [43], which inspired this study to hypothesize that the most important factors controlling gully-erosion might also be different. 


\section{Materials and Methods}

\subsection{Study Area}

The Minzir catchment is in the subhumid part of the upper Blue Nile river basin (Ethiopia) and covers a drainage area of $18 \mathrm{~km}^{2}$ (Figure 1). Its altitude ranges from 2030-2265 m a.s.l. with an average of $2095 \mathrm{~m}$ a.s.l. The catchment receives an average annual rainfall of $1480 \mathrm{~mm}$, of which more than $90 \%$ falls between May and October. The mean maximum monthly temperature is $30.0^{\circ} \mathrm{C}$ in March to $23.1^{\circ} \mathrm{C}$ in August, whereas the mean minimum monthly temperature is $5.4^{\circ} \mathrm{C}$ in December, with up to $13.1^{\circ} \mathrm{C}$ in May and June.

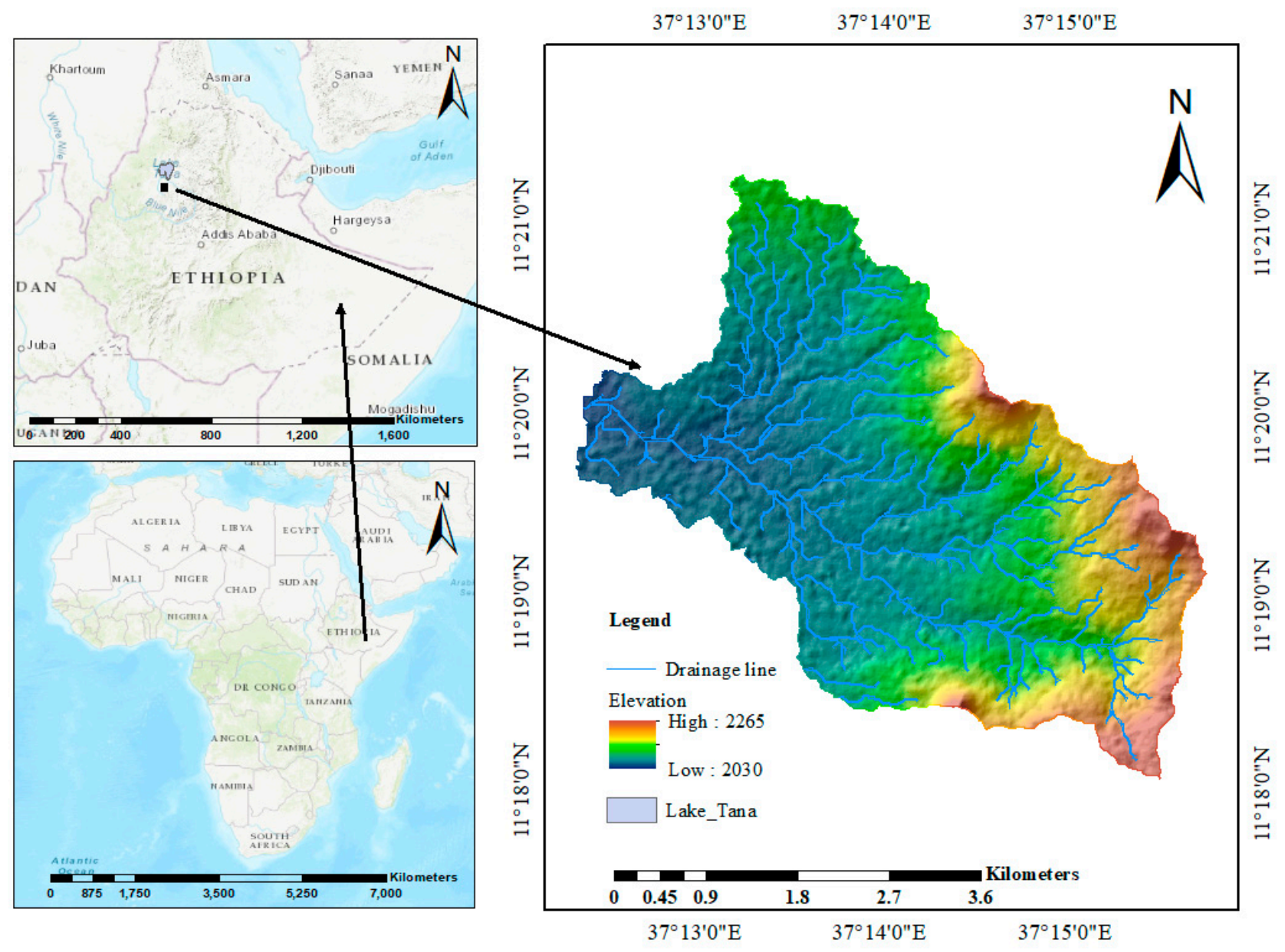

Figure 1. Study area map and elevation range of the Minzir catchment.

The geology is dominated by Quaternary basalts [44], with soil type dominantly being Nitisols (29.5\%), Vertisols (29.2\%), Luvisols (14.9\%), Leptosols (10\%), and Alisols (7.7\%). Cambisols, Fluvisols, and Regosols cover the remaining 5\% of the catchment. The soil texture is dominantly clay $(83.7 \%)$, clay loam $(5.9 \%)$, sandy clay loam $(3.5 \%)$, and loam (3.1\%). The major land cover in the study area is cultivated land (83\%), grassland (12.8\%), and plantation forest (1.6\%). Woodland, bushland, villages, and water bodies together comprise less than $3 \%$ of the catchment.

To reduce land degradation, different biological, agronomic, and physical soil and water conservation measures (e.g., bunds and check dams) were introduced in the catchment area [45]. Despite this effort, the amount of sediment reaching the Koga reservoir, which is located downstream of Minzir, is still significant and amounts to $25 \mathrm{Mg} \mathrm{ha}^{-1} \mathrm{y}^{-1}[46,47]$. Moreover, soil and water conservation efforts in the last 15 years resulted in only $35 \%$ reduction in soil erosion $[48,49]$. An increase in cultivated land and a decrease in woody vegetation has contributed to the increased sediment yield in the catchment [46]. 
The same study further stated that poorly planned and poorly constructed soil and water conservation measures are among the main causes of soil erosion in the catchment. A similar study from an adjacent catchment revealed that due to the lack of integrated approaches and the lack of maintenance, rehabilitation measures have not been able to reduce sediment in rivers [49]. This and an increase in cultivated land and a decrease in woody vegetation have contributed to the increased sediment yield in the catchment [46] in spite of the construction of rehabilitation measures.

\subsection{Data Collection and Preparation}

This research is organized as follows (see Figure 2): (1) data organization, including gully erosion inventory and selection of gully predictor factors; (2) multicollinearity test of gully predictor factors; (3) gully-erosion susceptibility mapping (GESM); (4) ranking gully predictor factors; (5) model validation.

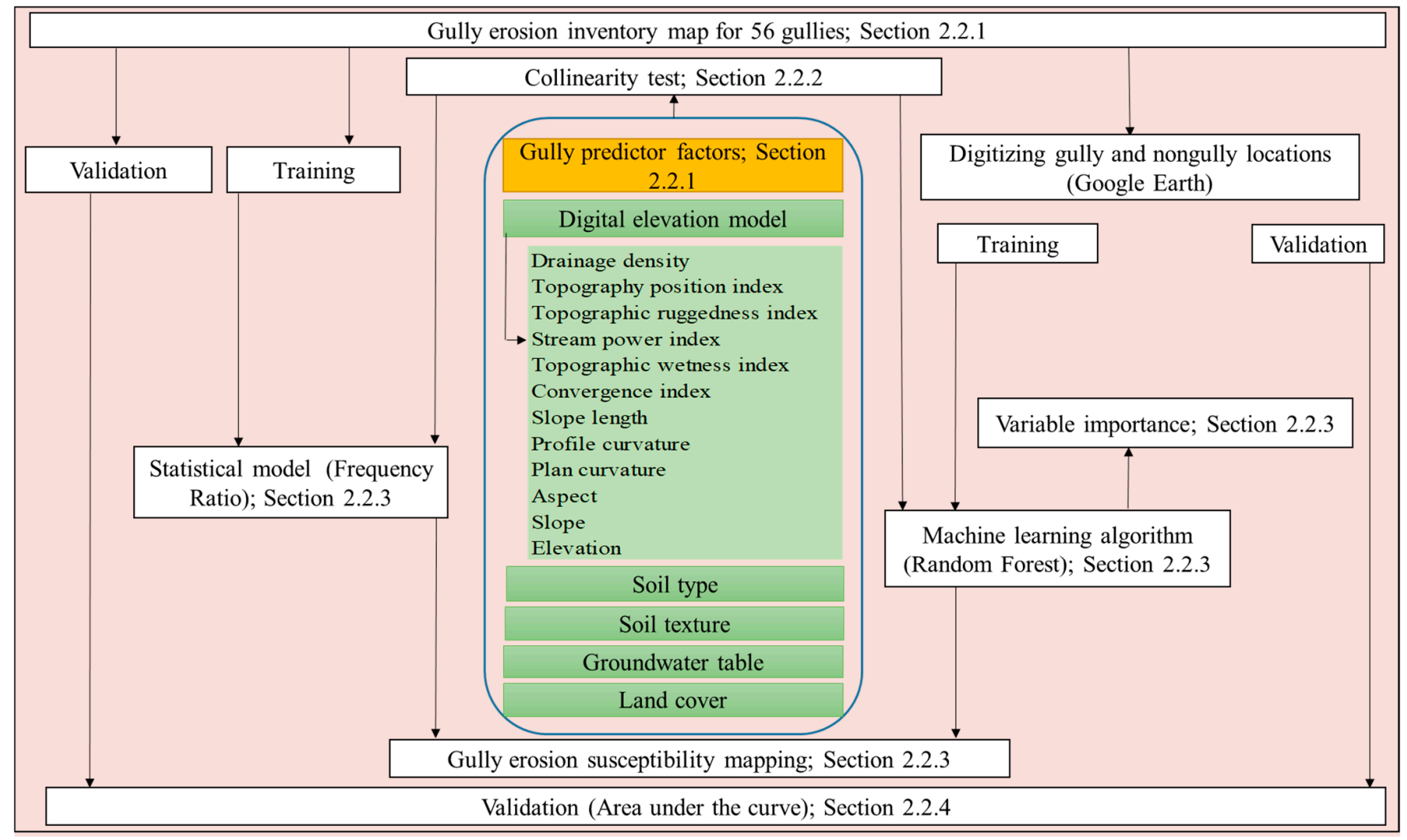

Figure 2. Research methodology flowchart.

\subsubsection{Data Organization}

- Gully erosion inventory

Gully erosion inventory data were prepared by combining field surveys with Google Earth ${ }^{\mathrm{TM}}$ imagery analysis. A total of 56 gullies were surveyed in the field; their morphology, including width, depth, length, and locations, were monitored. Then, the areal extent of each gully was derived by digitizing Google Earth imagery.

- Gully erosion predictor factors

From a literature review, 18 predictor factors that control gully erosion were selected from four data sets: digital elevation model (DEM), groundwater table, soil, and land cover (Table 1). We omitted those that do not vary throughout the catchment and do not have explanatory values in our modeling, such as geology and rainfall depth. Therefore, a 
total of 16 gully predictor factors, which have been subjected to the multicollinearity test (elaborated in Table 2), will be used.

Table 1. Data sources.

\begin{tabular}{cccc}
\hline Data Used & Description & Resolution & Source \\
\hline $\begin{array}{c}\text { Digital elevation model } \\
\text { (DEM) }\end{array}$ & $\begin{array}{c}\text { DEM telineate the catchment boundary } \\
\text { and river networks and characterize the } \\
\text { landscape. Topography plays an important } \\
\text { role in runoff processes and helps us to } \\
\text { understand the physical processes of } \\
\text { disaggregation, transport, and soil } \\
\text { deposition [50] }\end{array}$ & $12.5 \mathrm{~m}$ & $\begin{array}{c}\text { Advanced Land } \\
\text { Observing Satellite } \\
\text { (ALOS) }\end{array}$ \\
\hline Land use/cover & $\begin{array}{c}\text { Land use/cover and soil digital layer are } \\
\text { used to quantify the hydrological processes } \\
\text { and soil erosion in a catchment [51] }\end{array}$ & $12.5 \mathrm{~m}$ & Song et al. [52] \\
\hline Soil data & $\begin{array}{c}\text { This data set includes soil type and texture } \\
\text { data for the Minzir study catchment. }\end{array}$ & $1: 50,000$ & $\begin{array}{c}\text { Amhara Design and } \\
\text { Supervision Works } \\
\text { Enterprise, Ethiopia }\end{array}$ \\
\hline
\end{tabular}

In this study, we used groundwater table

(GWT) readings from 50 piezometers, reported for 2018. GWT was measured from

Groundwater level the soil surface to the location of the GWT. GWT surface was generated using inverse distance weighting (IDW) interpolation of

50 piezometers distributed across the catchment the observations using ArcGIS [52].

Note: vector maps of land use/cover and soil were reprocessed into 12.5-m rasters to match the DEM resolution.

To ascertain compatibility during modeling, maps of the gully inventory and predictor factors were rasterized to the same pixel size of $12.5 \mathrm{~m}$ as the DEM using ArcGIS 10.5. To extract different gully-erosion factors from the DEM, SAGA GIS 7.5 was used [53]. The first 12 factors presented in Table 2 were derived from DEM data.

The 1:50,000 scale soil data (soil type and soil texture) has an equivalent resolution of $25 \mathrm{~m}$. The nearest resampling technique [54] was used to match the soil data resolution with the DEM resolution. This resampling technique will not change the value of the cell. The maximum spatial error of applying the nearest resampling technique is one-half of the size of the cell.

Table 2. Description of gully predictor variables.

\begin{tabular}{|c|c|c|}
\hline Variable & Description & Classes/Class Range \\
\hline Elevation & $\begin{array}{l}\text { Determines vegetation distribution and rainfall patterns }[55,56] \text {, } \\
\text { which indirectly affect gully distribution }[24] .\end{array}$ & $2030-2265$ \\
\hline Slope & $\begin{array}{l}\text { Determines both the kinetic energy and the volume of surface runoff } \\
\text { [8], which, in turn, affects drainage density, discharge, and soil } \\
\text { erosion [24]. }\end{array}$ & $0-34$ \\
\hline Aspect & $\begin{array}{l}\text { Variation in aspect influences the distribution of vegetation by } \\
\text { influencing the rate of recharge, soil moisture content, and } \\
\text { evaporation that, in turn, control gully development }[57,58] \text {. }\end{array}$ & $\begin{array}{l}\text { Flat, North, Northeast, } \\
\text { East, Southeast, South, } \\
\text { Southwest, West, } \\
\text { Northwest, and North }\end{array}$ \\
\hline
\end{tabular}

Plan curvature, also known as contour curvature [59], is defined as "the rate of change of aspect along a contour" [60]. Plan curvature can

Plan curvature have positive, negative, and zero values representing convexity, concavity, and flatness, respectively [61]. Flow diverges on a convex slope and converges on a concave slope. 
Table 2. Cont.

\begin{tabular}{|c|c|c|}
\hline Variable & Description & Classes/Class Range \\
\hline Profile curvature & $\begin{array}{l}\text { Profile curvature is defined as "the rate of change of slope down a } \\
\text { flow line" [60], and its values can be positive, negative, and zero. } \\
\text { Profile curvature with positive values is concaved upward, with } \\
\text { slopes decreasing downhill and flows being accelerated. Profile } \\
\text { curvature with negative values is upwardly convexed, with slopes } \\
\text { increasing downhill and flows being decelerated. Zero values are } \\
\text { flat surfaces. }\end{array}$ & $-2.69-2.01$ \\
\hline $\begin{array}{l}\text { Convergence index } \\
\qquad(\mathrm{CI})\end{array}$ & $\begin{array}{l}\text { CI estimates the divergence (when CI is negative) and convergence } \\
\text { (positive) of flow in a given area; it is calculated on the basis of aspect } \\
\text { information [62]. }\end{array}$ & $-100-99.2$ \\
\hline $\begin{array}{l}\text { Topographic } \\
\text { ruggedness index } \\
\text { (TRI) }\end{array}$ & $\begin{array}{c}\text { TRI is a measure of topographic heterogeneity and is calculated on } \\
\text { the basis of relief and drainage [63]. The TRI value for flat areas is } \\
\text { zero, while the value for mountain areas with steep ridges is } \\
\text { positive [64]. }\end{array}$ & $0.35-19.6$ \\
\hline $\begin{array}{l}\text { Topography position } \\
\text { index (TPI) }\end{array}$ & $\begin{array}{l}\text { TPI is derived from DEM by comparing a given cell elevation to the } \\
\text { average of its surroundings [65]. The TPI value can be positive (when } \\
\text { the elevation of a location greater than the average of its } \\
\text { neighborhood), negative (when less than the surrounding areas), and } \\
\text { zero (for flat or constant slope) [66]. }\end{array}$ & $-7.90-22.8$ \\
\hline Slope length (LS) & $\begin{array}{c}\text { LS is defined as the distance between the start of overland flow to a } \\
\text { point where the slope gradient decreases sufficiently to cause } \\
\text { depositions [67]. LS influences soil erodibility and critical } \\
\text { shear stress [68]. }\end{array}$ & $0-772$ \\
\hline Drainage density (DD) & $\begin{array}{c}\text { Drainage density is a measure of stream length per unit of catchment } \\
\text { area [69] and is used as a predictor of gully erosion in many studies. } \\
\text { The soil drainage characteristics affect soil water retention capacity, } \\
\text { which, in turn, determines the rate of soil erosion [70]. }\end{array}$ & $0-2.2$ \\
\hline $\begin{array}{l}\text { Topographic wetness } \\
\text { index (TWI) }\end{array}$ & $\begin{array}{l}\text { TWI quantifies the effect of local topography over the hydrological } \\
\text { process and assesses the spatial distribution of soil moisture and } \\
\text { surface saturation [71]. In areas where saturation excess runoff is the } \\
\text { dominant process of gullies, TWI predicts saturated areas susceptible } \\
\text { to gullies [72]. }\end{array}$ & $2.89-17.6$ \\
\hline $\begin{array}{l}\text { Stream power index } \\
\text { (SPI) }\end{array}$ & $\begin{array}{l}\text { SPI estimates the erosive power of surface runoff as a result of the } \\
\text { relationship between discharge and catchment area [73]. Similarly, it } \\
\text { predicts the potential of streams to modify the geomorphology of a } \\
\text { catchment by gully erosion [74]. }\end{array}$ & $0-5965$ \\
\hline $\begin{array}{l}\text { Groundwater table } \\
\text { depth (GWT) }\end{array}$ & $\begin{array}{l}\text { Research conducted in humid and subhumid regions has shown that } \\
\text { elevated groundwater is one of the most important causes of gully } \\
\text { erosion }[18,75,76] \text {. Nevertheless, we do not see this important factor } \\
\text { incorporated in any of the gully erosion prediction models so far. }\end{array}$ & $0.01-4.05(\mathrm{~m})$ \\
\hline Soil type & $\begin{array}{l}\text { Although gullies can evolve on any soil type, the soil type determines } \\
\text { the size and shape of the gullies [77]. Therefore, integrating soil type } \\
\text { into gully modeling increases prediction accuracy. }\end{array}$ & $\begin{array}{l}\text { Alisols, Cambisols, } \\
\text { Ferralsols, Fluvisols, } \\
\text { Leptosols, Luvisols, } \\
\text { Nitisols, Regosols, and Vertisols. }\end{array}$ \\
\hline Soil texture & $\begin{array}{l}\text { Soil texture determines the rate of infiltration [78] and erosion } \\
\text { resistance, which determines the volume of gully erosion }[79,80]\end{array}$ & $\begin{array}{l}\text { Clay, clay loam, loam, sandy } \\
\text { clay, sandy clay loam, silty clay, } \\
\text { and silty clay loam. }\end{array}$ \\
\hline Land cover & $\begin{array}{l}\text { Land cover and gullies are closely linked [81] as land cover is one of } \\
\text { the factors that set the threshold for gully initiation [81] }\end{array}$ & $\begin{array}{l}\text { cultivated land, bushland, } \\
\text { plantation forest, village, } \\
\text { waterbody, woodland, } \\
\text { and grassland }\end{array}$ \\
\hline
\end{tabular}


The GWT surface generated using the IDW technique was resampled using the bilinear resampling technique. This method determines the new value of a cell based on a weighted distance average of the four nearest input cell centers [54]. This method is used for continuous data and will cause some smoothening of data.

\subsubsection{Multicollinearity Test}

In this study, multicollinearity was tested by combining results from the variance inflation factor (VIF) and tolerance (TOL), which are commonly used in different fields, including forest fire and gully erosion [41,82], with a correlation matrix of all predictor factors. The correlation method used in this study is the Pearson correlation coefficient. A correlation with a corresponding $p$-value of $>0.01$ is considered insignificant. The corrplot package, implemented in $\mathrm{R}$ statistical software, has been used to present the correlation matrix and the confidence interval graphically [83]. Tolerance is the reciprocal of VIF. Collinearity among predictor factors reduces model prediction accuracy [84]. Therefore, input factors with evidence of collinearity will be discarded before the GESM is developed.

\subsubsection{Gully Erosion Susceptibility Map (GESM) and Variable Importance}

Frequency ratio (FR) and random forest (RF) models discussed below were used to build the GESM. The GESM was finally classified as "low", "moderate", "high", and "very high" using the natural break method or the Jenks method in ArcGIS [85]. This classification method was selected as it reduces variance within a class. The RF model was also used to rank the most important gully erosion predictor factor.

- $\quad$ Frequency ratio (FR) model

As depicted in Equation (1), $F R$ is the ratio of gully erosion probability of occurrence to nonoccurrences within a gully predictor factor class $[29,41]$. This method is one of the simplest statistical bivariate techniques used in various fields, such as landslide susceptibility mapping [86]. Moreover, studies have shown that the FR model predicts gully susceptible areas very well $[36,87]$. The modeling was executed by randomly dividing the gullies into a training set $(n=39$ or $70 \%)$ and a validation set $(n=17$ or $30 \%)$. ArcGIS 10.5 was used to develop the GESM using the FR model.

$$
F R=(A / B) /(C / D)
$$

where $A$ is the number of gully erosion pixels for each class of predictor factors, $B$ is the total number of gully erosion pixels in the study area, $C$ is the number of pixels in each class of gully predictor factor, and $D$ is the number of total pixels in the study area.

The FR values obtained using Equation (1) were normalized using Equation (2).

$$
Y_{N F R}=\left(X_{F R}-M I N_{F R}\right) /\left(M A X_{F R}-M I N_{F R}\right)
$$

where $Y_{N F R}$ is the normalized frequency ratio, $X_{F R}$ is the frequency ratio of the class within a predictor factor, $M I N_{F R}$ is the minimum of all frequency ratios within a predictor factor, and $M A X_{F R}$ is the maximum of all the frequency ratios within a predictor factor.

Finally, the gully erosion susceptibility map is developed by summing up the normalized frequency ratio values for each predictor factors class.

- $\quad$ Random forest (RF) model

After conducting the multicollinearity test, gully erosion variable importance is computed using the RF model. The RF is known for effectively predicting variable importance in different disciplines, including land subsidence [88], invasive plant [89], groundwater [90], gully head susceptibility [31], and forest fire susceptibility [82]. The RF model is a multivariate nonparametric machine learning technique developed by Breiman [91]. The RF is a powerful decision tree classifier that predicts well when there is missing data, avoids over-fitting problems, produces more stable results, and is less sensitive to multicollinearity than other machine learning algorithms (e.g., support vector machine (SVM) 
and classification and regression tree (CART)) $[30,88,92,93]$. It is also known for predicting gully erosion very well compared to other machine learning algorithms [41].

The RF model was implemented in R statistical software [94]. As the analysis in the RF model was cell-based, a total of 2963 and 6560 gridded cells (12.5 by $12.5 \mathrm{~m}$ ) were extracted from the gully and nongully irregularly shaped sample spatial polygons, respectively.

The RF model works by growing many decorrelated decision trees as a base learner using a fraction of randomly selected gully observation and gully predictor factors, with replacement. Every tree was trained using $2 / 3$ of the randomly selected training samples, while the remaining $1 / 3$ training samples, named out-of-bag (OOB) samples, were used to validate the prediction result. Finally, the majority vote or mode rule was used to allocate a pixel to a class [95]. The mean decrease in the Gini index (or Gini impurity) was used as an indicator for variable importance of the evaluated gully-erosion predictors [96]. The mean decrease in Gini is the mean of the total decrease in node impurity of the variable (i.e., gully predictor factors), weighted by the proportion of samples reaching that node in each individual decision tree in the RF. A higher mean decrease in Gini indicates higher variable importance.

Determination of variable importance using the RF model was executed for three scenarios with different combinations of gully predictor factors: (1) keeping all 15 nonsoiltype gully predictor factors for Nitisol soils only (i.e., excluding other soil types); (2) keeping all 15 factors for Vertisol soils only (i.e., excluding other soil types), and (3) using all 16 variables (i.e., including all soil types in the analysis).

\subsubsection{Model Validation}

In this study, model performances were evaluated using the area under the ROC curve (AUC). A ROC curve is the plot of sensitivity versus 1-specificity for different threshold values. The area under the ROC curve (AUC) is a commonly used parameter for quantifying the quality of a classificator because it is a threshold-independent performance measure [97]. It is a valuable technique for visualizing and measuring the accuracy of the models [26], and its value ranges between 0.5 and 1, with the highest accuracy at 1 [29]. This method has been successfully used in gully erosion prediction research $[24,25,31]$.

\section{Results}

\subsection{Multicollinearity Test}

The multicollinearity test showed that the VIF ranges from 1.04 to 7.8 , while the TOL, which is the reciprocal of the VIF, varies from 0.13 to 0.96 (Table 3). VIF values greater than 5, with corresponding TOL values less than 0.2 , indicate serious multicollinearity among factors [98]. VIF values for TRI and slope are greater than 5 , suggesting multicollinearity (Table 3 ).

Table 3. Multicollinearity test statistics of gully predictor variables.

\begin{tabular}{ccc}
\hline \multirow{2}{*}{ Gully Predictor Variables } & \multicolumn{2}{c}{ Collinearity Statistics } \\
\cline { 2 - 3 } & Tolerance (TOL) & Variance Inflation Factors (VIF) \\
\hline Land cover & 0.88 & 1.13 \\
Plan curvature & 0.49 & 2.04 \\
Profile curvature & 0.56 & 1.79 \\
Texture & 0.79 & 1.27 \\
Aspect & 0.96 & 1.04 \\
Convergence index & 0.68 & 1.46 \\
Drainage density & 0.78 & 1.28 \\
Groundwater & 0.81 & 1.23 \\
Elevation & 0.36 & 2.75 \\
Slope length & 0.59 & 1.68 \\
Stream power index & 0.77 & 1.29 \\
Topographic position index & 0.65 & 1.54 \\
Terrain ruggedness index & 0.13 & 7.8 \\
\hline
\end{tabular}


Table 3. Cont.

\begin{tabular}{ccc}
\hline \multirow{2}{*}{ Gully Predictor Variables } & \multicolumn{2}{c}{ Collinearity Statistics } \\
\cline { 2 - 3 } & Tolerance (TOL) & Variance Inflation Factors (VIF) \\
\hline Topographic wetness index & 0.42 & 2.39 \\
Slope & 0.13 & 7.4 \\
Soil type & 0.5 & 1.99 \\
\hline
\end{tabular}

In addition to the multicollinearity test using the VIF method, the results of the correlation matrix (Figure 3) suggest that TRI and slope are strongly correlated (0.9), with a corresponding $p$-value of 0 (Figure S1), indicating that the correlation is significant. Guided by the results obtained using both the correlation matrix and VIF, we removed TRI and slope from the entire analysis. Besides, model prediction performance was evaluated by varying the number of gully predictor factors, depending on their importance presented in Figure 4c.

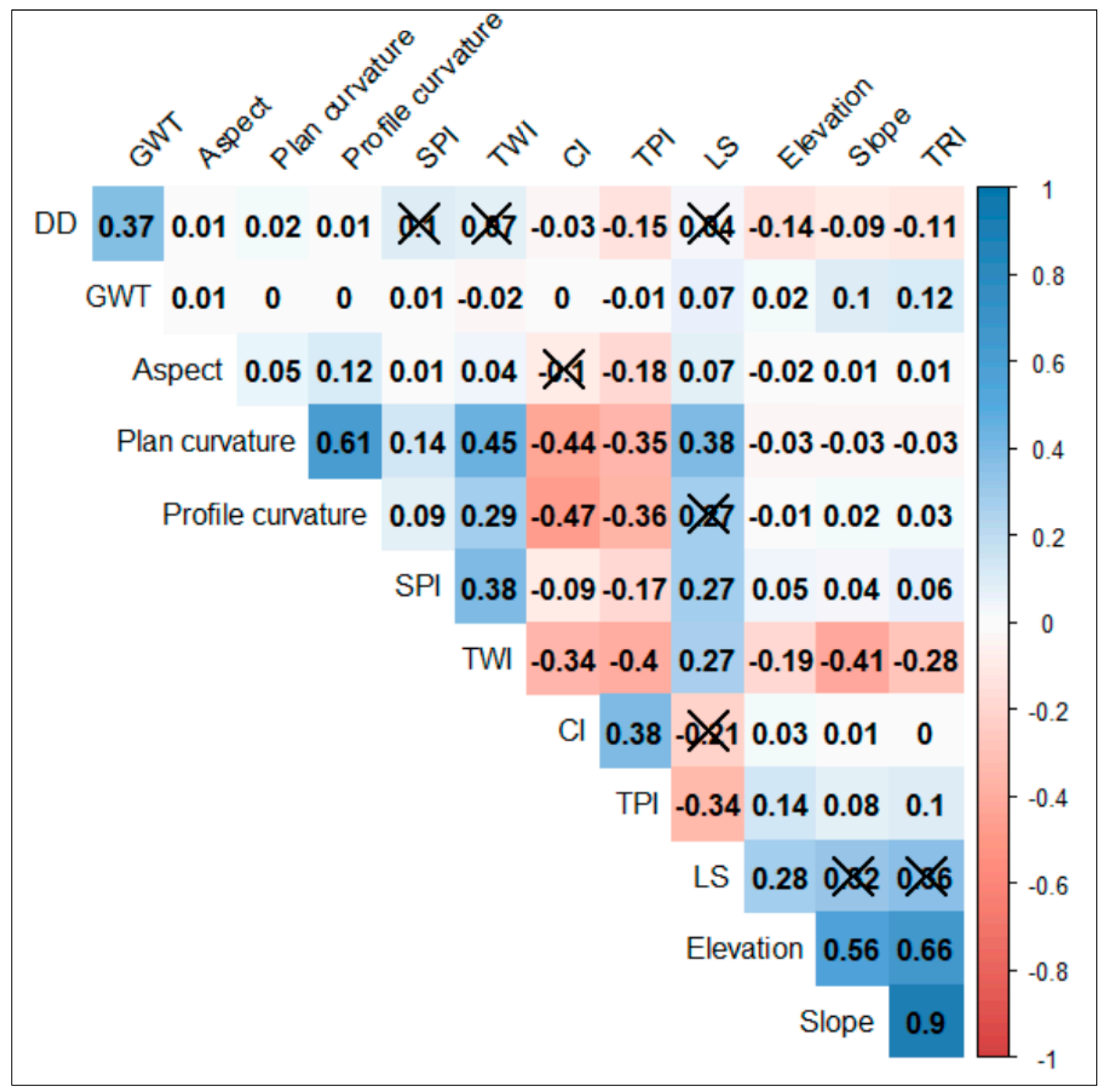

Figure 3. Correlation matrix for the 13 quantitative gully-erosion predictor factors. Crosses are added for correlations having $p$-values $>0.01$ or when the correlation is insignificant. 
(a)

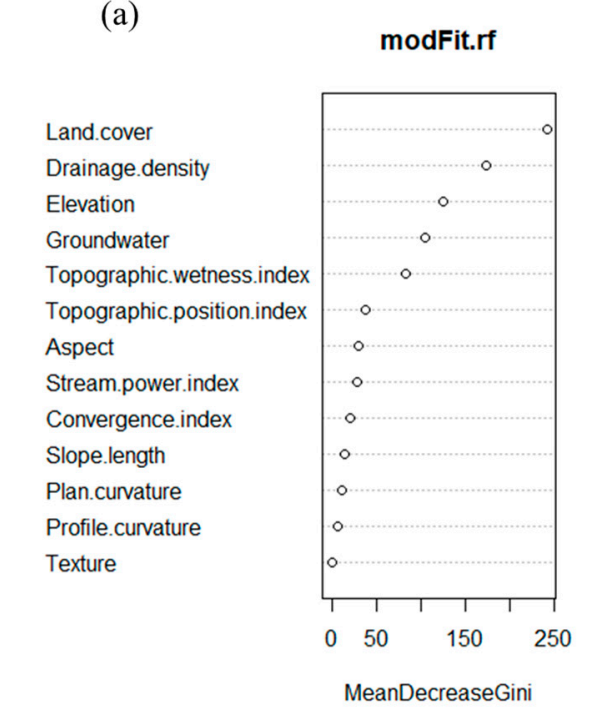

(b)

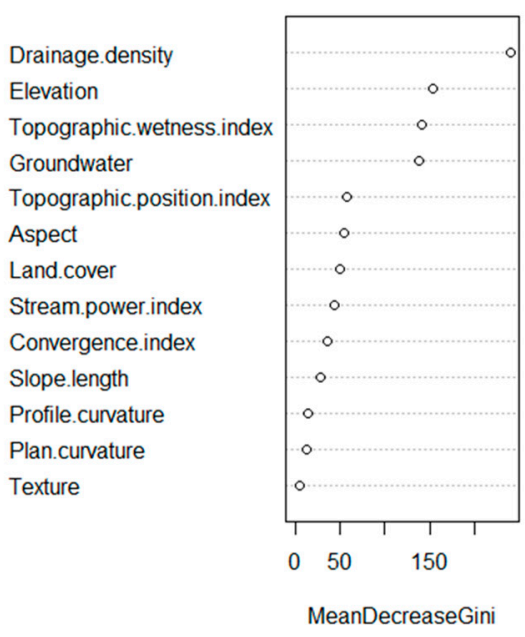

(c)

modFit.rf

Figure 4. Variable importance plot of gully-erosion predictor factors for (a) Nitisol soil type only, (b) Vertisol soil type only, and (c) all soil types.

\subsection{Gully Characteristics and Spatial Distribution}

The average width, depth, and length of the 56 gullies were 6, 1.6, and $227 \mathrm{~m}$, respectively (Table 4). Gullies in the study watershed occupy 16.8 hectares of land. On the basis of the average land-holding size ( $~ 0.7 \mathrm{ha})$ in the Ethiopian highlands [99], the land taken over by the gullies would have been able to support 24 households. Furthermore, the gullies in the study catchment are primarily located on cultivated land (57.45\%) and grasslands $(41.3 \%)$, indicating that they are eroding economically important land and, thereby, threatening the food security of the rural community.

Table 4. Statistical summary of the 56 surveyed gullies.

\begin{tabular}{ccccc}
\hline Parameter & Minimum & Maximum & Average & Median \\
\hline Width $(\mathrm{m})$ & 2.06 & 15 & 6.08 & 5.13 \\
Depth $(\mathrm{m})$ & 0.47 & 8.18 & 1.65 & 1.44 \\
Length (m) & 22.8 & 1463 & 227 & 134 \\
Area (ha) & 0.004 & 5.16 & 0.3 & 0.08 \\
\hline
\end{tabular}

Many of the gullies were found on valley bottoms compared to hillslope areas. A larger percentage $(>70 \%)$ of gullies were located on slope gradients less than $5 \%$, and for areas with flat $(48.1 \%)$ plan curvatures rather than concave and convex plan curvatures. Many gully pixels were also found at lower elevations (2030-2070 $\mathrm{m}$ a.s.l. and 2070-2104 $\mathrm{m}$ a.s.l.) compared to high elevation classes. Furthermore, though the flat aspect class occupied a relatively small area, a larger percentage of gullies were found on lands with a flat aspect.

\subsection{Gully Erosion Susceptibility Mapping and Variable Importance}

\subsubsection{FR Model}

The frequency ratio values listed in Table 5 provide a spatial relationship between gully locations and predictor factors (see Figures S2-S15). When FR values are greater than 1 in a given gully-erosion predictor class, the class may be considered susceptible to gullies [87]. Here, we will present the FR values of the top 4 gully-erosion predictor classes that provide the best FR model accuracy. However, this does not mean that the other gully predictor factors do not play a role in gully erosion, but only that the top four important predictor factors well illustrated the effects of these factors. 
Table 5. (1) Areal coverage of gully predictor factors and training gully pixels and (2) the frequency ratio (FR) and normalized frequency ratio (NFR) calculated for the training data set.

\begin{tabular}{|c|c|c|c|c|c|c|c|}
\hline Factors & Class & $\begin{array}{l}\text { Pixels in } \\
\text { Domain }\end{array}$ & $\begin{array}{l}\% \text { of Pixels } \\
\text { in Domain }\end{array}$ & $\begin{array}{c}\text { Training } \\
\text { Gully Pixels } \\
\text { in Domain }\end{array}$ & $\begin{array}{c}\% \text { of Gully } \\
\text { Training Pixels } \\
\text { in Domain }\end{array}$ & FR & NFR \\
\hline \multirow[t]{5}{*}{$\mathrm{CI}$} & $-100--42.75$ & 12,282 & 10.8 & 320 & 14.5 & 1.34 & 1 \\
\hline & $-42.7--10.6$ & 22,765 & 19.9 & 509 & 23 & 1.15 & 0.65 \\
\hline & $-10.6-9$ & 44,119 & 38.7 & 805 & 36.4 & 0.94 & 0.27 \\
\hline & 9-39.6 & 22,656 & 19.8 & 391 & 17.7 & 0.89 & 0.18 \\
\hline & $39.6-99.2$ & 12,274 & 10.7 & 188 & 8.49 & 0.79 & 0 \\
\hline \multirow[t]{5}{*}{ Elevation } & 2030-2070 & 42,552 & 37.3 & 836 & 37.8 & 1.01 & 0.66 \\
\hline & 2070-2104 & 33,214 & 29.1 & 984 & 44.5 & 1.53 & 1 \\
\hline & 2104-2141 & 18,891 & 16.6 & 360 & 16.3 & 0.98 & 0.64 \\
\hline & 2141-2186 & 14,494 & 12.7 & 33 & 1.49 & 0.12 & 0.08 \\
\hline & $2186-2265$ & 4945 & 4.33 & 0 & 0 & 0 & 0 \\
\hline \multirow[t]{3}{*}{ Plan curvature } & Concave & 31,069 & 27.2 & 502 & 22.7 & 0.83 & 0 \\
\hline & Flat & 52,826 & 46.3 & 1076 & 48.6 & 1.05 & 0.86 \\
\hline & Convex & 30,201 & 26.5 & 635 & 28.7 & 1.08 & 1 \\
\hline \multirow[t]{5}{*}{ Profile curvature } & $-2.69--0.75$ & 4566 & 4 & 72 & 3.25 & 0.81 & 0 \\
\hline & $-0.75--0.31$ & 27,155 & 23.8 & 446 & 20.1 & 0.85 & 0.07 \\
\hline & $-0.31-0.30$ & 50,120 & 43.9 & 1017 & 45.9 & 1.05 & 0.50 \\
\hline & $0.30-0.75$ & 27,292 & 23.9 & 555 & 25.1 & 1.05 & 0.50 \\
\hline & $0.75-2.01$ & 4963 & 4.35 & 123 & 5.56 & 1.28 & 1 \\
\hline \multirow[t]{5}{*}{ LS (m) } & 0-25 & 79,752 & 69.9 & 1463 & 66.1 & 0.94 & 0 \\
\hline & $25-78$ & 23,282 & 20.4 & 468 & 21.1 & 1.04 & 0.12 \\
\hline & $78-163$ & 7754 & 6.79 & 207 & 9.35 & 1.38 & 0.59 \\
\hline & $163-315$ & 2601 & 2.28 & 52 & 2.35 & 1.03 & 0.12 \\
\hline & 315-772 & 707 & 0.62 & 23 & 1.04 & 1.68 & 1 \\
\hline \multirow[t]{5}{*}{ TPI } & -7.90 to -1.61 & 14,649 & 12.8 & 618 & 27.9 & 2.17 & 1 \\
\hline & -1.61 to -0.17 & 37,952 & 33.3 & 838 & 37.9 & 1.14 & 0.47 \\
\hline & $-0.17-1.19$ & 40,363 & 35.4 & 575 & 30 & 0.73 & 0.27 \\
\hline & $1.19-3.67$ & 19,316 & 16.9 & 175 & 7.91 & 0.47 & 0.13 \\
\hline & $3.67-22.8$ & 1816 & 1.59 & 7 & 0.32 & 0.2 & 0 \\
\hline \multirow[t]{5}{*}{ SPI } & 0-128 & 110,406 & 96.8 & 1999 & 90.3 & 0.93 & 0 \\
\hline & $128-507$ & 2643 & 2.32 & 106 & 4.79 & 2.07 & 0.24 \\
\hline & 507-1170 & 743 & 0.65 & 80 & 3.61 & 5.55 & 1 \\
\hline & 1170-2365 & 238 & 0.21 & 21 & 0.95 & 4.55 & 0.78 \\
\hline & $2365-5965$ & 66 & 0.06 & 7 & 0.32 & 5.47 & 0.98 \\
\hline \multirow[t]{5}{*}{ TWI } & $2.89-5.86$ & 42,422 & 37.2 & 665 & 30 & 0.81 & 0 \\
\hline & $5.86-7.15$ & 35,986 & 31.5 & 612 & 27.7 & 0.88 & 0.03 \\
\hline & $7.15-8.67$ & 19,052 & 16.7 & 385 & 17.4 & 1.04 & 0.12 \\
\hline & $8.67-10.7$ & 12,163 & 10.7 & 314 & 14.2 & 1.33 & 0.27 \\
\hline & $10.7-17.6$ & 4473 & 3.92 & 237 & 10.7 & 2.73 & 1 \\
\hline \multirow[t]{5}{*}{$\mathrm{DD}\left(\mathrm{km} \mathrm{km}^{-2}\right)$} & $0-0.2$ & 45,742 & 40.1 & 300 & 13.5 & 0.34 & 0 \\
\hline & $0.2-0.5$ & 30,765 & 26.9 & 998 & 45.1 & 1.67 & 1 \\
\hline & $0.5-0.9$ & 21,601 & 18.9 & 619 & 28 & 1.48 & 0.85 \\
\hline & $0.9-1.4$ & 12,484 & 10.9 & 231 & 10.4 & 0.95 & 0.46 \\
\hline & $1.4-2.2$ & 3504 & 3.07 & 65 & 2.94 & 0.96 & 0.46 \\
\hline \multirow[t]{7}{*}{ land cover } & Cultivated land & 94,296 & 82.6 & 1243 & 56.2 & 0.68 & 0.21 \\
\hline & Bushland & 951 & 0.83 & 11 & 0.5 & 0.6 & 0.18 \\
\hline & Plantation forest & 2173 & 1.90 & 0 & 0 & 0 & 0 \\
\hline & Village & 431 & 0.38 & 0 & 0 & 0 & 0 \\
\hline & Waterbody & 62 & 0.05 & 0 & 0 & 0 & 0 \\
\hline & Woodland & 1153 & 1.01 & 21 & 0.95 & 0.94 & 0.29 \\
\hline & Grassland & 15,030 & 13.2 & 938 & 42.4 & 3.22 & 1 \\
\hline \multirow[t]{4}{*}{ Soil type } & Alisols & 8800 & 7.71 & 102 & 4.61 & 0.6 & 0.17 \\
\hline & Cambisols & 2743 & 2.40 & 163 & 7.36 & 3.06 & 0.89 \\
\hline & Ferralsols & 4262 & 3.73 & 0 & 0 & 0 & 0 \\
\hline & Fluvisols & 1782 & 1.56 & 119 & 5.38 & 3.44 & 1 \\
\hline
\end{tabular}


Table 5. Cont.

\begin{tabular}{|c|c|c|c|c|c|c|c|}
\hline Factors & Class & $\begin{array}{l}\text { Pixels in } \\
\text { Domain }\end{array}$ & $\begin{array}{l}\% \text { of Pixels } \\
\text { in Domain }\end{array}$ & $\begin{array}{c}\text { Training } \\
\text { Gully Pixels } \\
\text { in Domain }\end{array}$ & $\begin{array}{c}\% \text { of Gully } \\
\text { Training Pixels } \\
\text { in Domain }\end{array}$ & FR & NFR \\
\hline \multirow{11}{*}{ Texture } & Leptosols & 11,390 & 9.98 & 46 & 2.08 & 0.21 & 0.06 \\
\hline & Luvisols & 16,893 & 14.8 & 168 & 7.59 & 0.51 & 0.15 \\
\hline & Nitosols & 33,675 & 29.5 & 615 & 27.8 & 0.94 & 0.27 \\
\hline & Regosols & 1284 & 1.12 & 0 & 0 & 0 & 0 \\
\hline & Vertisols & 33,267 & 29.1 & 1000 & 45.2 & 1.55 & 0.45 \\
\hline & Clay & 95,486 & 83.7 & 2149 & 97.1 & 1.16 & 0.47 \\
\hline & Clay loam & 6676 & 5.85 & 44 & 1.99 & 0.34 & 0.14 \\
\hline & Loam & 3503 & 3.07 & 0 & 0 & 0 & 0 \\
\hline & Sandy clay & 373 & 0.33 & 18 & 0.81 & 2.49 & 1 \\
\hline & Sandy clay loam & 3960 & 3.47 & 0 & 0 & 0 & 0 \\
\hline & Silty clay & 1423 & 1.25 & 2 & 0.09 & 0.07 & 0.03 \\
\hline \multirow{4}{*}{ GWT (m) } & Silty clay loam & 2675 & 2.34 & 0 & 0 & 0 & 0 \\
\hline & $0-1.03$ & 2514 & 2.20 & 2 & 0.09 & 0.04 & 0 \\
\hline & $1.03-1.51$ & 8718 & 7.64 & 227 & 10.2 & 1.34 & 1 \\
\hline & $1.51-1.95$ & 38,198 & 33.5 & 994 & 44.9 & 1.34 & 0.99 \\
\hline \multirow{11}{*}{ Aspect } & $1.95-2.42$ & 36,005 & 31.5 & 622 & 28.1 & 0.89 & 0.65 \\
\hline & $2.42-4.05$ & 28,661 & 25.1 & 368 & 16.6 & 0.66 & 0.48 \\
\hline & Flat & 4915 & 4.31 & 85 & 3.84 & 0.89 & 0.43 \\
\hline & North & 12,441 & 10.9 & 85 & 3.84 & 0.35 & 0.04 \\
\hline & Northeast & 7781 & 6.82 & 44 & 1.99 & 0.29 & 0 \\
\hline & East & 4312 & 3.78 & 34 & 1.54 & 0.41 & 0.08 \\
\hline & Southeast & 8028 & 7.04 & 151 & 6.82 & 0.97 & 0.48 \\
\hline & South & 13,624 & 11.9 & 448 & 20.2 & 1.694 & 1 \\
\hline & Southwest & 23,504 & 20.6 & 675 & 30.5 & 1.484 & 0.85 \\
\hline & West & 20,385 & 17.9 & 410 & 18.5 & 1.04 & 0.53 \\
\hline & Northwest & 19,106 & 16.7 & 281 & 12.7 & 0.76 & 0.33 \\
\hline
\end{tabular}

Though large areas (40\%) were covered by the DD class between 0 and $0.2 \mathrm{~km} \mathrm{~km}^{-2}$, they had the smallest FR (0.34) and were less vulnerable to gully erosion. Drainage density $\left(0.2-0.5\right.$ and $\left.0.5-0.9 \mathrm{~km} \mathrm{~km}^{-2}\right)$, with FR 1.67 and 1.48 , respectively, were the most susceptible areas for gully formation. Drainage density of $0.9-1.4$ and $1.4-2.2 \mathrm{~km} \mathrm{~km}^{-2}$ covers a small portion of the catchment, has relatively smaller FR values, and is less susceptible to gully erosion.

Based on FR values, the vulnerability to gully erosion increases with a decline in elevation. Low elevations (2030-2070 and 2070-2104 m a.s.1.), with FR 1.21 and 1.27, were the most susceptible areas for gully formation, while higher elevation areas showed little to no susceptibility to gully erosion.

Grassland (for grazing) with an FR value of 3.22 was the most susceptible area to gully-erosion. Though large areas were cultivated $(82.7 \%)$, they had smaller FR $(0.68)$ and were less prone to gully erosion. Other land uses, such as bushland, woodland, and plantation forests, were also less correlated with gully erosion.

The FR values also showed that gullies are positively correlated with shallower GWT zones. GWT depths (1.03-1.51 and 1.51-1.95 m) were found to have a higher FR (1.34) value, indicating that they are strongly correlated with gully erosion. Conversely, areas with deeper GWT had lower FR values, reflecting lower susceptibility to gully erosion. Areas with GWT depths between 0 and 1.03 occupy a small percentage of the catchment $(2 \%)$ and are less prone to gully erosion $(\mathrm{FR}=0.04)$.

Figure 5a presents the GESM obtained using the FR model. Susceptibility is classified as "low", "moderate", "high", and "very high." The classifications were made using the natural break method or the Jenks method in ArcGIS [85]: 13.9\%, 23.8\%, 45.5\%, and 16.8\% for "low", "moderate", "high", and "very high" classes, respectively. 


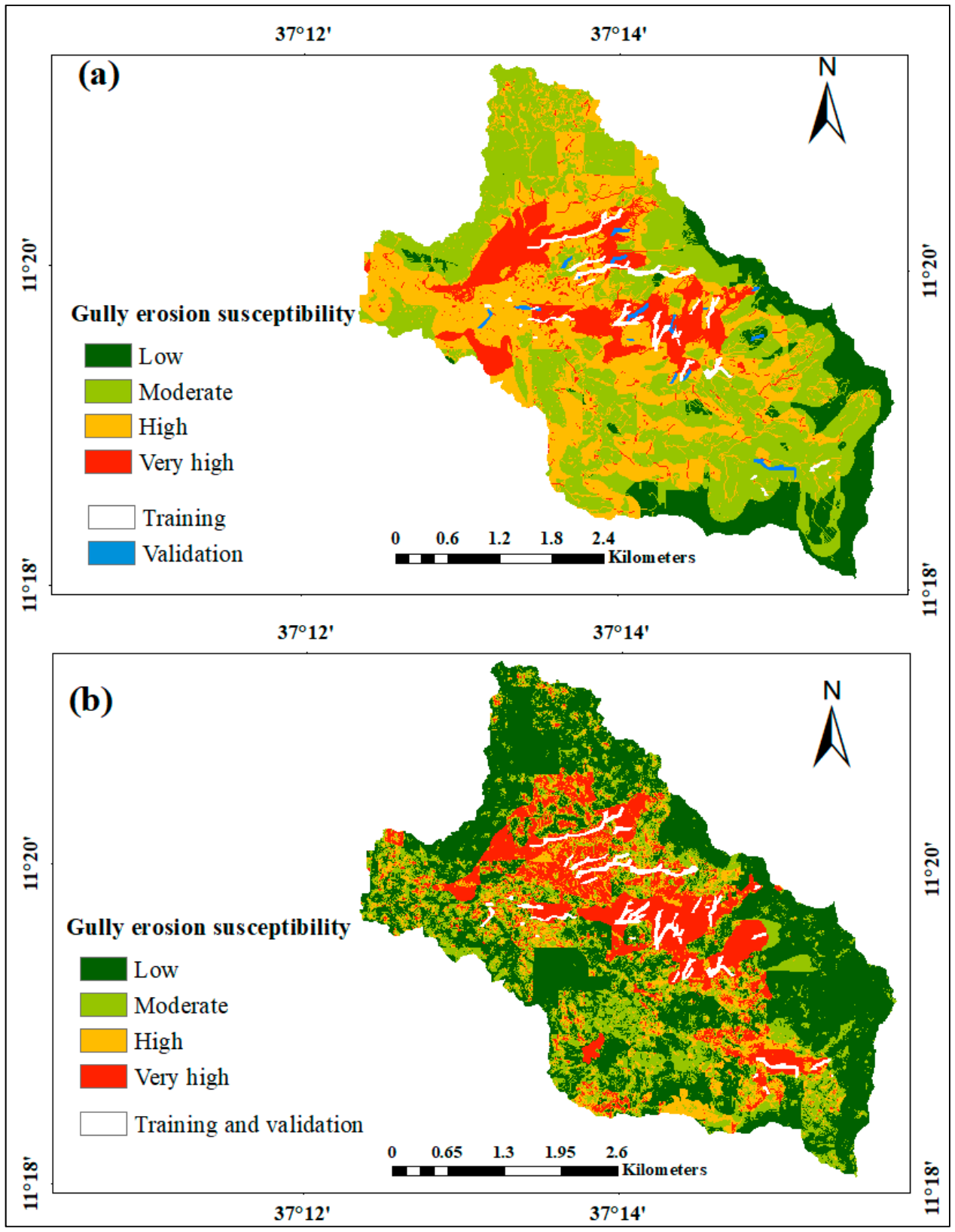

Figure 5. Gully erosion susceptibility map using (a) frequency ratio and (b) random forest models: for this model, the training and validation gully polygon takes the same white color as the model that classifies the training and validation data internally.

\subsubsection{RF Model}

The magnitude and rate of gully expansion differ between Nitisols and Vertisols [43]; therefore, the most important gully predictor factors were examined separately for these soils (Figure $4 a, b$ ) in addition to all the soil types (Figure 4c).

Based on the mean decrease in Gini index values for the Nitisol soil type (Figure 4), the five most important gully-erosion predictor factors were land use (242.4), DD (173.8), elevation (124.9), GWT (105.3), and TWI (83.4), respectively. For the Vertisol soil type (Figure $4 \mathrm{~b}$ ), the five most important gully-erosion predictor factors were DD (240.4), elevation (153.5), TWI (141.4), GWT (140.0), and TPI (57.3). With soil type included as a gully-erosion predictor factor, the most important variables were DD (625.9), elevation (416.6), land cover (331.3), GWT (330.7), TWI (293.5), and soil type (225.7) (Figure 4c). In general, factors such as texture, CI, LS, and profile and plan curvature had little importance 
to explain gully-erosion in the study area. Despite the degree of importance of each factor, all 16 factors have been identified as important except for textures with no significance for gully development in Nitisol.

The RF-model-derived GESM is presented in Figure 5b. The Jenks algorithm in ArcGIS [85] was used to determine the "low", "moderate", "high", and "very high" susceptibility classes at the class break of $46.7 \%, 20.8 \%, 13 \%$, and $19 \%$, respectively.

The percentage of gully erosion susceptibility class for Vertisols and Nitisols is presented in Figure 6. Class breaks of the low, moderate, high, and very high susceptibility classes in Nitisol are $47.9 \%, 18.8 \%, 19.8 \%$, and $13.5 \%$, whereas in the Vertisol class, breaks are $33.7 \%, 23.7 \%, 17.2 \%$, and $25 \%$, respectively. One can see that the areas with a low susceptibility class are higher for Nitisols than Vertisols. In contrast, the most susceptible area in Vertisols is approximately two times higher than in Nitisols. For the moderate and high susceptible classes, similar predictions have been obtained for both soils.

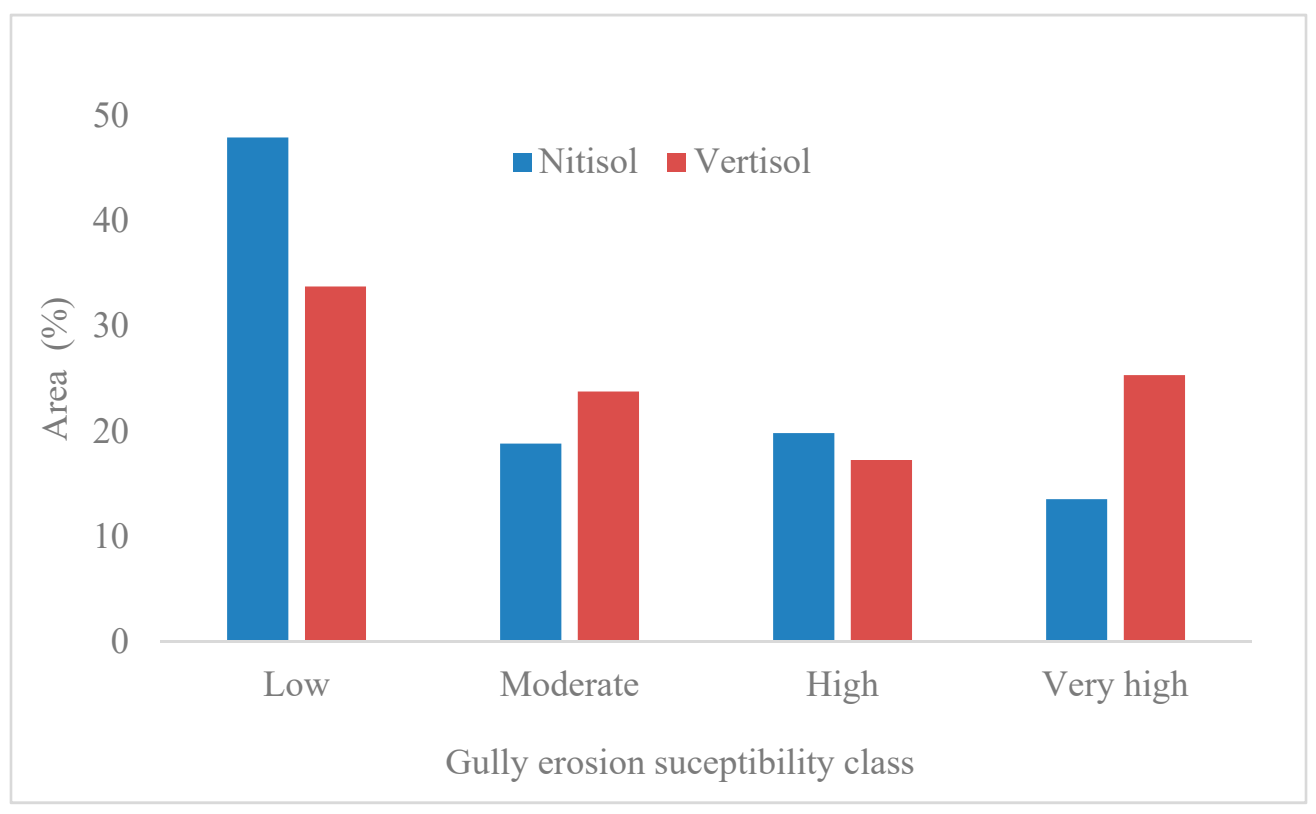

Figure 6. Gully erosion susceptibility in Nitisol and Vertisol soils.

\subsection{Model Validation}

Model performance for the FR and RF models was evaluated for five scenarios (Figure 7). The first case involved all predictor factors (i.e., using the 14 gully-predictor factors, excluding TRI and slope), which is called "All" hereafter. The second case used the top six factors obtained from Figure 4c, which is called "Top6" hereafter. The third case used all the top six gully-predictor factors but excluded soil type, called "exclSoil" hereafter. The fourth case involved all the top six gully-predictor factors but excluded GWT, called "exclGWT" hereafter. The third and fourth cases were evaluated to see the predictive potential of the newly introduced parameters (i.e., soil type and GWT) for gully prediction. In the fifth scenario, the top four factors obtained from Figure $4 \mathrm{c}$ were used; this scenario is called "Top4" hereafter.

The prediction accuracy of models using AUC is categorized as poor (0.5-0.6), average (0.6-0.7), good (0.7-0.8), very good (0.8-0.9), and excellent (0.9-1) [100]. In the case of $\mathrm{RF}$, all five scenarios demonstrated excellent model prediction accuracy. The Top4 and Top6 model scenarios provided the best AUC values (99.9\%). A higher AUC value (99.8\%) was also obtained for the All model scenario in the RF model. Prediction accuracy after excluding soil type (exclSoil) and GWT (exclGWT) from the top six factors was $97.9 \%$ and $99.3 \%$, respectively. 

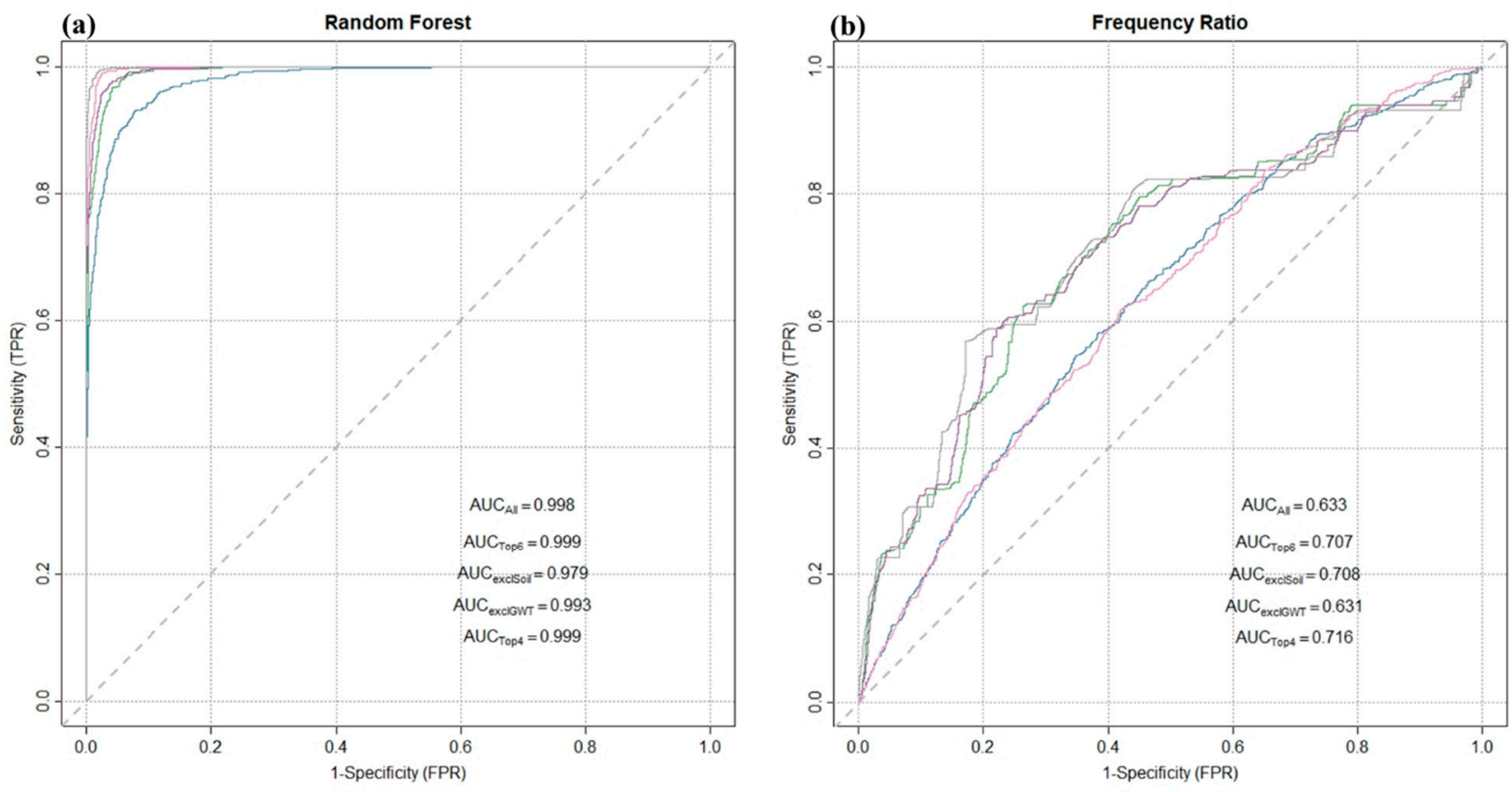

Figure 7. Receiver operating characteristic (ROC) curves for the random forest (a) and frequency ratio (b) models. Model performance was evaluated for five different cases: (1) All: using all predictor factors; (2) Top6: using the top six factors, as presented in Figure 4c; (3) exclSoil: using all top six gully-predictor factors except soil type; (4) exclGWT: using all top six gully-predictor factors except GWT; and (5) Top4: using the top four factors, as presented in Figure 4c.

Prediction accuracy using the FR model ranged from average to good. Similar to the RF model, the highest prediction accuracy (AUC $=71.6 \%$ ) was obtained for the Top4 FR model. The AUC values for the exclSoil and Top6 models were $70.8 \%$ and $70.7 \%$, respectively. Lower AUC values were obtained for the All model (AUC $=63.3 \%$ ) and the exclGWT model (AUC $=63.1 \%$ ). Excluding the GWT reduced the FR model prediction accuracy by about 7\%, whereas excluding the soil type did not affect the FR model's performance.

\section{Discussion}

\subsection{Spatial Distribution of Gullies and Gully-Erosion Predictor Variable Importance}

All 16 gully-erosion predictor factors were found to be important for the development of gullies in the Minzir catchment, at different levels of importance. However, gully erosion prediction using the FR and RF models showed that the best prediction accuracy was obtained using the top four most important gully-predictor factors. This suggests that the impact of the other factors on gully erosion is well illustrated by DD, elevation, land use, and GWT.

DD was found to be the most important factor that determines gully location in the study catchment. Studies have shown that gully erosion susceptibility increases with increasing DD $[33,101,102]$. The FR values obtained in this study are the highest for the middle DD classes, and smaller values were obtained for the two highest classes. As described above, gully erosion is dominantly a function of four major factors. Therefore, lower FR values for the two highest DD classes may be attributed to little contribution from the other three gully predictor factors. For example, the GWT in this area was the deepest, indicating little susceptibility to gully erosion.

Elevation was found to be the second most important gully-erosion predictor factor. The two lower elevation classes (2030-2070 and 2070-2104 $\mathrm{m}$ a.s.1.) had the largest gullied area, which was revealed by high FR values obtained for these classes (Table 5). This finding is consistent with studies in subhumid Iran, which found low elevation areas to be vulnerable to gullies due to the presence of concentrated flow [42].

The third-most important gully-erosion predictor factor was land use/cover. This is consistent with studies that found land cover as one of the most important factors 
determining gully locations [31,38,61]. While in the Minzir catchment, the area of grazing land $(13.2 \%)$ is smaller than that of cultivated land $(82.7 \%)$, it has the largest proportion of gullies, which was revealed by a high FR value (Table 5). Studies have stated that grazing lands are more susceptible to gully-erosion than other land-use groups $[25,42,77]$. Moreover, $[103,104]$ reported that the conversion of forest land to cultivated and grazing land had resulted in increased gully erosion. Land-use change affects gully erosion by altering the hydrological and physicochemical properties of the soil. For instance, in tropical Brazil, grazing has increased the amount of surface runoff that, in turn, increased saturated area and subsurface flow in valley bottoms, which has led to gully development [76]. Forest plantations have resulted in a double increase in organic carbon and steady-state infiltration, thereby improving aggregate stability [105]. It was found that uncultivated land had twice as much soil organic carbon as 50-year-old cultivated land, which enhances soil aggregate stability and, therefore, increases soil resistance to erosion [106].

The relationship between the spatial distribution of gullies and the elevation of the terrain and slope suggested that gullies are mainly located at the valley bottom. This finding is in agreement with [24,33], who reported that due to concentrated flow, valley bottoms are more vulnerable to gullies. Field observations have also shown that intensified agricultural activities in the valley bottom expose the catchment to all forms of land degradation.

The fourth most important factor that determines gully erosion is GWT. Gullies have been observed in all classes of GWT, but FR values have shown that areas with GWT depths shallower than $2 \mathrm{~m}$ are the most susceptible to gullies (Table 5). This is consistent with most studies in subhumid Ethiopia, where elevated groundwater increases soil pore water pressure and enhances gully erosion rate $[13,21]$. This is also in agreement with the findings of [43], who have reported a higher gully head retreat rate (about four times) for gullies with shallower GWT than areas with deeper GWT.

\subsection{Gully Susceptibility in Vertisols and Nitisols}

Both Nitisols and Vertisols, which are the dominant soils in the study catchment, were found to be vulnerable to gully erosion (Table 5). However, both the GESM and the FR value showed that Vertisols are more prone to gully erosion than Nitisols. The RF-model-derived GESM showed that "low" susceptible classes in Nitisols (47.9\%) were larger than Vertisols (33.7\%), whereas "very high" susceptible classes were larger in the Vertisols (25\%) than the Nitisols (13.7\%). This is in line with the finding by [43] that higher moisture retention capacity, poor drainage, and elevated GWT lead to increased pore water pressure, which results in higher rates of gully erosion in Vertisols than in Nitisols that have lower water retention capacity and deeper GWT. In addition, Nitisols are a well-drained soil type [107] that reduces gully erosion due to both concentrated flow and soil saturation. Additionally, [108] found that the high swelling and shrinkage nature of Vertisols makes them more sensitive to gully erosion. The FR values also show that Fluvisols and Cambisols, which occupy a very small percentage of the catchment, are susceptible to gullies.

The results of separate variable importance analyses for Nitisols and Vertisols showed land cover and drainage densities as the number-one factor determining the location of the gully in each soil, respectively. Land cover for Vertisols was ranked number nine, suggesting it has little significance for gully-erosion in this soil. The other important gullyerosion factors (i.e., elevation, TWI, and GWT) are similar for both soils. Further research is needed on the fact that land cover is the most important gully-erosion factor for Nitisols.

\subsection{Model Performance and Comparison}

The performance of the FR models ranged from average to good, whereas, for the RF model, excellent prediction accuracy was obtained. Excellent model performance was achieved for all five models in the RF model. FR model performance was average for the models exclGWT and All, whereas Top4, Top6, and exclSoil models performed good. The Top4 model performed best in both RF and FR cases than the rest of the four models. This 
suggests that despite the importance of all predictor factors for gully erosion, gully erosion can successfully be predicted using only DD, elevation, land cover, and GWT.

The impact of excluding GWT and soil type as gully erosion predictor factors had a smaller impact on the RF model performance, whereas excluding GWT from the top six parameters caused a $7 \%$ reduction in the AUC value of the FR model. This shows the high explanatory power of the GWT parameter on the FR model. Moreover, GWT is among the top four most important parameters that determine gully locations. Therefore, accounting for this parameter in future gully erosion prediction research can provide better gully erosion prediction accuracy, especially in subhumid areas. Excluding soil type from the FR model did not affect the model performance. Despite this, soil type being the sixth most important factor determining gully development suggests its significance for gully erosion.

The excellent model performance in all five RF model scenarios may attribute to the ensemble learning algorithm in the RF model that works on majority voting principles by growing a large collection of decorrelated decision trees (or models) as a base learner. As a result, a single classifier error in RF model is outweighed by the majority [109], whereas FR is a single model. Furthermore, RF can handle high dimensionality (high numbers of attributes) and large datasets better than FR.

The excellent prediction accuracy achieved by the RF model is in agreement with [38] and [31], who have successfully mapped gully erosion and gully head susceptible areas. The FR model employed in this study predicts gully areas better than other statistical models such as weight of evidence and index of entropy [36,42].

Current approaches towards gully erosion susceptibility mapping in the Ethiopian highland are based on topographical threshold factors such as topographic wetness index (TWI) and stream power index (SPI) [39,40]. The application of these thresholds is flawed, primarily because streams and saturated-bottom lands are preferentially considered most vulnerable to gullies. However, our findings have shown that TWI and SPI importance on gully erosion is limited compared to the top four factors we have presented in this study, which have provided the best model prediction accuracy. Therefore, the finding of this research can be used for the successful planning and design of gully reclamation measures in a catchment.

\section{Conclusions}

There is no single factor responsible for the formation of gullies in the study area; all 16 factors we examined were found to be important for the development of gullies in the Minzir catchment. However, gully erosion prediction using the FR and RF models showed that the best prediction accuracy was obtained using the top four most important gully-predictor factors: drainage density, elevation, land use, and groundwater. This suggests that the impact of other gully-erosion parameters is well illustrated by the top four important gully-erosion predictor factors. The separate variable importance analysis for Nitisols and Vertisols showed land cover and drainage densities, respectively, as the most important factors that determine gully locations. The other most important factors for both soils were more or less similar. The fact that land cover is the most important factor for the development of gullies in Nitisols requires further investigation. The results of this study suggest that future planning and implementation of conservation measures in subhumid regions of Ethiopia should target areas with higher drainage density, low-lying areas, grazing land, and shallower groundwater table, which have been shown to be vulnerable to gully erosion.

Frequency ratio (FR) and random forest (RF) models have been identified as useful techniques for mapping gully erosion vulnerable areas and identifying the most important gully erosion predictor factor. The performance of the FR models ranged from average to good, whereas for the RF model, excellent prediction accuracy was obtained. The gully erosion susceptibility map developed in this study can be used to plan informed gully erosion rehabilitation and prevention measures in the Minzir catchment. As sediment from gullies threatens the entire upper Blue Nile basin, a water source for many water 
resource development activities, we recommend similar studies in different agroecology and geomorphic settings within the degraded Ethiopian highlands.

Supplementary Materials: The following are available online at https:/ /www.mdpi.com/2073-444 1/13/2/216/s1, Figure S1: A plot of p-values, Figure S2: Land cover map, Figure S3: Plan curvature map, Figure S4: Profile curvature map, Figure S5: Soil texture map, Figure S6: Aspect map, Figure S7: Convergence index map, Figure S8: Drainage density map, Figure S9: Groundwater table map, Figure S10: Elevation map, Figure S11: Slope length map, Figure S12: Stream power index map, Figure S13: Topography position index map, Figure S14: Topographic wetness index map, Figure S15: Soil type map.

Author Contributions: Conceptualization, S.A., E.L., S.K., M.v.d.P., H.L., and S.E.A.T.M.v.d.Z.; data curation, S.A. and H.L.; formal analysis, S.A., H.G., and H.L.; methodology, S.A., E.L., H.G., and H.L.; project administration, S.A., S.K., M.v.d.P., and S.E.A.T.M.v.d.Z.; supervision, E.L., S.K., M.v.d.P., and S.E.A.T.M.v.d.Z.; writing—review and editing, S.A., E.L., S.K., M.v.d.P., H.G., H.L., and S.E.A.T.M.v.d.Z. All authors have read and agreed to the published version of the manuscript.

Funding: This research was funded by NFP (Netherlands Fellowship Program) (grant number 5160957248) and the Schlumberger Foundation, Faculty for the Future Program. Their support is gratefully acknowledged.

Data Availability Statement: The data presented in this study are available in the article.

Acknowledgments: The author would like to thank Bahir Dar University for providing the opportunity to undertake her Ph.D. Finally, we are very grateful to all the farmers and development agents that live in the study area of the Minzir catchment for providing access to their lands and for being cooperative during the data collection period.

Conflicts of Interest: The authors declare no conflict of interest.

\section{References}

1. Ryken, N.; Vanmaercke, M.; Wanyama, J.; Isabirye, M.; Vanonckelen, S.; Deckers, J.; Poesen, J. Impact of papyrus wetland encroachment on spatial and temporal variabilities of stream flow and sediment export from wet tropical catchments. Sci. Total Environ. 2015, 511, 756-766. [CrossRef] [PubMed]

2. Ionita, I.; Niacsu, L.; Petrovici, G.; Blebea-Apostu, A.M. Gully development in eastern Romania: A case study from Falciu Hills. Nat. Hazards 2015, 79, 113-138. [CrossRef]

3. Tilahun, S.A.; Ayana, E.K.; Guzman, C.D.; Dagnew, D.C.; Zegeye, A.D.; Tebebu, T.Y.; Yitaferu, B.; Steenhuis, T.S. Revisiting storm runoff processes in the upper Blue Nile basin: The Debre Mawi watershed. Catena 2016, 143, 47-56. [CrossRef]

4. Frankl, A.; Deckers, J.; Moulaert, L.; Van Damme, A.; Haile, M.; Poesen, J.; Nyssen, J. Integrated Solutions for Combating Gully Erosion in Areas Prone to Soil Piping: Innovations from the Drylands of Northern Ethiopia. Land Degrad. Dev. 2016, 27, 1797-1804. [CrossRef]

5. Casalí, J.; Giménez, R.; Bennett, S. Gully erosion processes: Monitoring and modelling. Earth Surf. Process. Landf. 2009, 34, 1839-1840. [CrossRef]

6. Poesen, J.; Nachtergaele, J.; Verstraeten, G.; Valentin, C. Gully erosion and environmental change: Importance and research needs. Catena 2003, 50, 91-133. [CrossRef]

7. Nyssen, J.; Poesen, J.; Veyret-Picot, M.; Moeyersons, J.; Haile, M.; Deckers, J.; Dewit, J.; Naudts, J.; Teka, K.; Govers, G. Assessment of gully erosion rates through interviews and measurements: A case study from northern Ethiopia. Earth Surf. Process. Landf. 2006, 31, 167-185. [CrossRef]

8. Valentin, C.; Poesen, J.; Li, Y. Gully erosion: Impacts, factors and control. Catena 2005, 63, 132-153. [CrossRef]

9. Tamene, L.; Vlek, P.L.G. Assessing the potential of changing land use for reducing soil erosion and sediment yield of catchments: A case study in the highlands of northern Ethiopia. Soil Use Manag. 2007, 23, 82-91. [CrossRef]

10. Girmay, G.; Nyssen, J.; Poesen, J.; Bauer, H.; Merckx, R.; Haile, M.; Deckers, J. Land reclamation using reservoir sediments in Tigray, northern Ethiopia. Soil Use Manag 2012, 28, 113-119. [CrossRef]

11. Haregeweyn, N.; Poesen, J.; Nyssen, J.; De Wit, J.; Haile, M.; Govers, G.; Deckers, S. Reservoirs in Tigray (Northern Ethiopia): Characteristics and sediment deposition problems. Land Degrad. Dev. 2006, 17, 211-230. [CrossRef]

12. Nyssen, J.; Poesen, J.; Moeyersons, J.; Haile, M.; Deckers, J. Dynamics of soil erosion rates and controlling factors in the Northern Ethiopian highlands-Towards a sediment budget. Earth Surf. Process. Landf. 2008, 33, 695-711. [CrossRef]

13. Tebebu, T.Y.; Abiy, A.Z.; Zegeye, A.D.; Dahlke, H.E.; Easton, Z.M.; Tilahun, S.A.; Collick, A.S.; Kidnau, S.; Moges, S.; Dadgari, F.; et al. Surface and subsurface flow effect on permanent gully formation and upland erosion near Lake Tana in the northern highlands of Ethiopia. Hydrol. Earth Syst. Sci. 2010, 14, 2207-2217. [CrossRef] 
14. Nyssen, J.; Poesen, J.; Moeyersons, J.; Deckers, J.; Haile, M.; Lang, A. Human impact on the environment in the Ethiopian and Eritrean highlands-A state of the art. Earth Sci. Rev. 2004, 64, 273-320. [CrossRef]

15. Monsieurs, E.; Dessie, M.; Adgo, E.; Poesen, J.; Deckers, J.; Verhoest, N.; Nyssen, J. Seasonal Surface Drainage of Sloping Farmland: A Review of Its Hydrogeomorphic Impacts. Land Degrad. Dev. 2015, 26, 35-44. [CrossRef]

16. Frankl, A.; Poesen, J.; Scholiers, N.; Jacob, M.; Haile, M.; Deckers, J.; Nyssen, J. Factors controlling the morphology and volume (V)-length (L) relations of permanent gullies in the northern Ethiopian Highlands. Earth Surf. Process. Landf. 2013, 38, 1672-1684. [CrossRef]

17. Zegeye, A.D.; Langendoen, E.J.; Stoof, C.R.; Tilahun, S.A.; Dagnew, D.C.; Zimale, F.A.; Guzman, C.D.; Yitaferu, B.; Steenhuis, T.S. Morphological dynamics of gully systems in the subhumid Ethiopian Highlands: The Debre Mawi watershed. Soil 2016, 2, 443-458. [CrossRef]

18. Addisie, M.B.; Ayele, G.K.; Gessess, A.A.; Tilahun, S.A.; Zegeye, A.D.; Moges, M.M.; Schmitter, P.; Langendoen, E.J.; Steenhuis, T.S. Gully head retreat in the sub-humid Ethiopian highlands: The Ene-Chilala catchment. Land Degrad Dev. 2017, 28, 1579-1588. [CrossRef]

19. Nyssen, J.; Poesen, J.; Moeyersons, J.; Luyten, E.; Veyret-Picot, M.; Deckers, J.; Haile, M.; Govers, G. Impact of road building on gully erosion risk: A case study from the Northern Ethiopian Highlands. Earth Surf. Process. Landf. 2002, 27, 1267-1283. [CrossRef]

20. Frankl, A.; Poesen, J.; Deckers, J.; Haile, M.; Nyssen, J. Gully head retreat rates in the semi-arid highlands of Northern Ethiopia. Geomorphology 2012, 173-174, 185-195. [CrossRef]

21. Ayele, G.K.; Addisie, M.B.; Langendoen, E.J.; Tegegne, N.H.; Tilahun, S.A.; Moges, M.A.; Nicholson, C.F.; Steenhuis, T.S. Evaluating erosion control practices in an actively gullying watershed in the highlands of Ethiopia. Earth Surf. Process. Landf. 2018, 43, 2835-2843. [CrossRef]

22. Billi, P.; Dramis, F. Geomorphological investigation on gully erosion in the Rift Valley and the northern highlands of Ethiopia. (Gully erosion and global change). Catena 2003, 50, 353-368. [CrossRef]

23. Zegeye, A.D.; Langendoen, E.J.; Guzman, C.D.; Dagnew, D.C.; Amare, S.D.; Tilahun, S.A.; Steenhuis, T.S. Gullies, a critical link in landscape soil loss: A case study in the subhumid highlands of Ethiopia. Land Degrad. Dev. 2018, 29, 1222-1232. [CrossRef]

24. Arabameri, A.; Blaschke, T.; Pradhan, B.; Pourghasemi, H.R.; Tiefenbacher, J.P.; Bui, D.T. Evaluation of Recent Advanced Soft Computing Techniques for Gully Erosion Susceptibility Mapping: A Comparative Study. Sensors 2020, 20, 335. [CrossRef]

25. Kariminejad, N.; Hosseinalizadeh, M.; Pourghasemi, H.R.; Bernatek-Jakiel, A.; Campetella, G.; Ownegh, M. Evaluation of factors affecting gully headcut location using summary statistics and the maximum entropy model: Golestan Province, NE Iran. Sci. Total Environ. 2019, 677, 281-298. [CrossRef] [PubMed]

26. Sameen, M.I.; Pradhan, B.; Lee, S. Self-learning random forests model for mapping groundwater yield in data-scarce areas. Nat. Resour. Res. 2019, 28, 757-775. [CrossRef]

27. Sevgen, E.; Kocaman, S.; Nefeslioglu, H.A.; Gokceoglu, C. A novel performance assessment approach using photogrammetric techniques for landslide susceptibility mapping with logistic regression, ann and random forest. Sensors 2019, 19, 3940. [CrossRef]

28. Yusri, S.; Retnowati, E.; Prastowo, M.; Idris, F. Combining Participatory Mapping, Cloud Computing and Machine Learning for Mapping Climate Induced Landslide Susceptibility in Lembeh Island, North Sulawesi. In Proceedings of the 7th Low Carbon Asia Research Network Annual Meeting: Challenges for Asia to Meet 1.5C Target, LoCARNet, Jakarta, Indonesia, 21-22 November 2018.

29. Park, S.; Kim, J. Landslide susceptibility mapping based on random forest and boosted regression tree models, and a comparison of their performance. Appl. Sci. 2019, 9, 942. [CrossRef]

30. Chen, W.; Li, Y.; Xue, W.; Shahabi, H.; Li, S.; Hong, H.; Wang, X.; Bian, H.; Zhang, S.; Pradhan, B.; et al. Modeling flood susceptibility using data-driven approaches of naïve Bayes tree, alternating decision tree, and random forest methods. Sci. Total Environ. 2020, 701. [CrossRef]

31. Hosseinalizadeh, M.; Kariminejad, N.; Chen, W.; Pourghasemi, H.R.; Alinejad, M.; Mohammadian Behbahani, A.; Tiefenbacher, J.P. Gully headcut susceptibility modeling using functional trees, naïve Bayes tree, and random forest models. Geoderma 2019, 342, 1-11. [CrossRef]

32. Zhao, Y.; Cheng, D. Collapsing Gullies Susceptibility Mapping Based on Entropy Information Value in Jiangxi Province of China. In Proceedings of the 39th IEEE International Geoscience and Remote Sensing Symposium, IGARSS, Yokohama, Japan, 28 July-2 August 2019; pp. 3471-3474.

33. Javidan, N.; Kavian, A.; Pourghasemi, H.R.; Conoscenti, C.; Jafarian, Z. Gully erosion susceptibility mapping using multivariate adaptive regression splines-replications and sample size scenarios. Water 2019, 11, 2319. [CrossRef]

34. Azareh, A.; Rahmati, O.; Rafiei-Sardooi, E.; Sankey, J.B.; Lee, S.; Shahabi, H.; Ahmad, B.B. Modelling gully-erosion susceptibility in a semi-arid region, Iran: Investigation of applicability of certainty factor and maximum entropy models. Sci. Total Environ. 2019, 655, 684-696. [CrossRef] [PubMed]

35. Arabameri, A.; Pradhan, B.; Lombardo, L. Comparative assessment using boosted regression trees, binary logistic regression, frequency ratio and numerical risk factor for gully erosion susceptibility modelling. Catena 2019, 183. [CrossRef]

36. Rahmati, O.; Haghizadeh, A.; Pourghasemi, H.R.; Noormohamadi, F. Gully erosion susceptibility mapping: The role of GIS-based bivariate statistical models and their comparison. Nat. Hazards 2016, 82, 1231-1258. [CrossRef]

37. Rahmati, O.; Tahmasebipour, N.; Haghizadeh, A.; Pourghasemi, H.R.; Feizizadeh, B. Evaluation of different machine learning models for predicting and mapping the susceptibility of gully erosion. Geomorphology 2017, 298, 118-137. [CrossRef] 
38. Arabameri, A.; Pradhan, B.; Rezaei, K. Gully erosion zonation mapping using integrated geographically weighted regression with certainty factor and random forest models in GIS. J. Environ. Manag. 2019, 232, 928-942. [CrossRef]

39. Assefa, T.T.; Jha, M.K.; Tilahun, S.A.; Yetbarek, E.; Adem, A.A.; Wale, A. Identification of erosion hotspot area using GIS and MCE technique for koga watershed in the upper Blue Nile Basin, Ethiopia. Am. J. Environ. Sci. 2015, 11, 245-255. [CrossRef]

40. Mhiret, D.A.; Dagnew, D.C.; Assefa, T.T.; Tilahun, S.A.; Zaitchik, B.F.; Steenhuis, T.S. Erosion hotspot identification in the sub-humid Ethiopian highlands. Ecohydrol. Hydrobiol. 2018. [CrossRef]

41. Gayen, A.; Pourghasemi, H.R.; Saha, S.; Keesstra, S.; Bai, S. Gully erosion susceptibility assessment and management of hazard-prone areas in India using different machine learning algorithms. Sci. Total Environ. 2019, 668, 124-138. [CrossRef]

42. Zabihi, M.; Mirchooli, F.; Motevalli, A.; Darvishan, A.K.; Pourghasemi, H.R.; Zakeri, M.A.; Sadighi, F. Spatial modelling of gully erosion in Mazandaran Province, northern Iran. Catena 2018, 161, 1-13. [CrossRef]

43. Amare, S.; Steenhuis, T.; van der Ploeg, M.; Langendoen, E.; Keesstra, S.; Belete, W.; Carranza, C.; Tilahun, S.; Zee, S.v.d. Hydrological and soil controls on valley bottom gully head erosion in the Ethiopian highland, Minzir catchment. Manuscript under review for publication. 2021.

44. Williams, F.M. Understanding Ethiopia. In Geology and Scenery; Springer: Cham, Switzerland, 2016.

45. Jemberu, W.; Baartman, J.E.M.; Fleskens, L.; Ritsema, C.J. Participatory assessment of soil erosion severity and performance of mitigation measures using stakeholder workshops in Koga catchment, Ethiopia. J. Environ. Manag. 2018, 207, $230-242$. [CrossRef] [PubMed]

46. Yeshaneh, E.; Salinas, J.L.; Blöschl, G. Decadal Trends of Soil Loss and Runoff in the Koga Catchment, Northwestern Ethiopia. Land Degrad. Dev. 2017, 28, 1806-1819. [CrossRef]

47. Mekonnen, M.; Keesstra, S.D.; Baartman, J.E.M.; Stroosnijder, L.; Maroulis, J. Reducing Sediment Connectivity Through man-Made and Natural Sediment Sinks in the Minizr Catchment, Northwest Ethiopia. Land Degrad. Dev. 2017, 28, 708-717. [CrossRef]

48. Molla, T.; Sisheber, B. Estimating soil erosion risk and evaluating erosion control measures for soil conservation planning at Koga watershed in the highlands of Ethiopia. Solid Earth 2017, 8, 13-25. [CrossRef]

49. Dagnew, D.C.; Guzman, C.D.; Zegeye, A.D.; Tibebu, T.Y.; Getaneh, M.; Abate, S.; Zemale, F.A.; Ayana, E.K.; Tilahun, S.A.; Steenhuis, T.S. Impact of conservationractices on runoff and soil loss in the sub-humid Ethiopian Highlands: The Debre Mawi watershed. J. Hydrol. Hydromech. 2015, 63, 210-219. [CrossRef]

50. Oliveira, A.H.; da Silva, M.A.; Silva, M.L.N.; Curi, N.; Neto, G.K.; de Freitas, D.A.F. Development of topographic factor modeling for application in soil erosion models. In SORIANO, MCH Soil Processes and Current Trends in Quality Assessment; InTech: Rijeka, Croatia, 2013; pp. 111-138.

51. Arnold, J.G.; Kiniry, J.; Srinivasan, R.; Williams, J.; Haney, E.; Neitsch, S. Soil and Water Assessment Tool Input/Output Documentation Version 2012; Texas Water Resources Institute: College Station, TX, USA, 2012; Volume 7.

52. Watson, D.F.; Philip, G. A refinement of inverse distance weighted interpolation. Geo Process. 1985, 2, $315-327$.

53. Conrad, O.; Bechtel, B.; Bock, M.; Dietrich, H.; Fischer, E.; Gerlitz, L.; Wehberg, J.; Wichmann, V.; Böhner, J. System for automated geoscientific analyses (SAGA) v. 2.1. 4. Geosci. Model. Dev. Discuss. 2015, 8, 2271-2312. [CrossRef]

54. GISGeography. Raster Resampling for Discrete and Continuous Data. Available online: https://gisgeography.com/rasterresampling/ (accessed on 13 December 2020).

55. Joseph, S.; Anitha, K.; Srivastava, V.; Reddy, C.; Thomas, A.; Murthy, M. Rainfall and elevation influence the local-scale distribution of tree community in the southern region of Western Ghats biodiversity hotspot (India). Int. J. For. Res. 2012, 2012. [CrossRef]

56. Jin, X.; Zhang, Y.; Schaepman, M.E.; Clevers, J.; Su, Z.; Cheng, J.; Jiang, J.; van Genderen, J. Impact of elevation and aspect on the spatial distribution of vegetation in the Qilian mountain area with remote sensing data. In Proceedings of the XXI Congress: Silk Road for Information from Imagery and Remote Sensing (ISPRS 2008), Beijing, China, 3-11 July 2008; The International Society for Photogrammetry: Hannover, Germany; pp. 1385-1390.

57. Wang, L.; Wei, S.; Horton, R.; Shao, M. Effects of vegetation and slope aspect on water budget in the hill and gully region of the Loess Plateau of China. Catena 2011, 87, 90-100. [CrossRef]

58. Patton, P.C.; Schumm, S.A. Gully erosion, Northwestern Colorado: A threshold phenomenon. Geology 1975, 3, 88-90. [CrossRef]

59. Peckham, S.D. Profile, plan and streamline curvature: A simple derivation and applications. Proc. Geomorphometry 2011, 4, 27-30.

60. Wilson, J.P.; Gallant, J.C. Terrain Analysis: Principles and Applications; John Wiley \& Sons: Hoboken, NJ, USA, 2000.

61. Conforti, M.; Aucelli, P.P.C.; Robustelli, G.; Scarciglia, F. Geomorphology and GIS analysis for mapping gully erosion susceptibility in the Turbolo stream catchment (Northern Calabria, Italy). Nat. Hazards 2011, 56, 881-898. [CrossRef]

62. Thommeret, N.; Bailly, J.; Puech, C. Robust extraction of Thalwegs networks from DTMs for topological characterisation: A case study on badlands. Proc. Geomorphometry 2009, 31, 218-223.

63. Shankar, S.; Dharanirajan, K. Drainage morphometry of flood prone rangat watershed, middle Andaman, India-A geospatial approach. Int. J. Innov. Technol. Explor. Eng. 2014, 3, 15-22.

64. Amatulli, G.; Domisch, S.; Tuanmu, M.-N.; Parmentier, B.; Ranipeta, A.; Malczyk, J.; Jetz, W. A suite of global, cross-scale topographic variables for environmental and biodiversity modeling. Sci. Data 2018, 5, 180040. [CrossRef] [PubMed]

65. Jenness, J. Topographic Position Index (tpi_jen. avx) Extension for ArcView 3. x, v. 1.3 ; Jenness Enterprises: Flagstaff, AZ, USA, 2006.

66. Weiss, A. Topographic position and landforms analysis. In Proceedings of the Poster Presentation, ESRI User Conference, San Diego, CA, USA, 9-13 July 2001. 
67. Gayen, A.; Saha, S. Application of weights-of-evidence (WoE) and evidential belief function (EBF) models for the delineation of soil erosion vulnerable zones: A study on Pathro river basin, Jharkhand, India. Modeling Earth Syst. Environ. 2017, 3, 1123-1139. [CrossRef]

68. Zhang, Q.; Dong, Y.; Lei, T.; Yang, Z.; Zhang, A.; Liu, X. Effects of detachment capacity on soil erodibility to concentrated flow with flume experiments. In Proceedings of the 2017 ASABE Annual International Meeting, Spokane, Washington, DC, USA, 16-19 July 2017.

69. Brandt, J.; Geeson, N.; Zucca, C. Desertification indicator system for mediterranean europe (DIS4ME). In Proceedings of the AIDCCD-Active Exchange of Experience on Indicators and Development of Perspectives in the Context of UNCCD. Local and Regional Desertification Indicators in a Global Perspective, International Seminar, Beijing, China, 16-18 May 2005; Enne, G., Yeroyanni, M., Eds.; pp. 43-58.

70. Lowery, B.; Swan, J.; Schumacher, T.; Jones, A. Physical properties of selected soils by erosion class. J. Soil Water Conserv. 1995, 50, 306-311.

71. Qin, C.-Z.; Zhu, A.-X.; Pei, T.; Li, B.-L.; Scholten, T.; Behrens, T.; Zhou, C.-H. An approach to computing topographic wetness index based on maximum downslope gradient. Precis. Agric. 2011, 12, 32-43. [CrossRef]

72. Gómez-Gutiérrez, Á.; Conoscenti, C.; Angileri, S.E.; Rotigliano, E.; Schnabel, S. Using topographical attributes to evaluate gully erosion proneness (susceptibility) in two mediterranean basins: Advantages and limitations. Nat. Hazards 2015, 79, 291-314. [CrossRef]

73. Shit, P.K.; Paira, R.; Bhunia, G.; Maiti, R. Modeling of potential gully erosion hazard using geo-spatial technology at Garbheta block, West Bengal in India. Model. Earth Syst. Environ. 2015, 1, 2. [CrossRef]

74. Vijith, H.; Dodge-Wan, D. Modelling terrain erosion susceptibility of logged and regenerated forested region in northern Borneo through the Analytical Hierarchy Process (AHP) and GIS techniques. Geoenviron. Disasters 2019, 6, 8. [CrossRef]

75. Thomas, J.T.; Iverson, N.R.; Burkart, M.R. Bank-collapse processes in a valley-bottom gully, western Iowa. Earth Surf. Process. Landf. 2009, 34, 109-122. [CrossRef]

76. Marinho, G.V.; de Castro, S.S.; de Campos, A.B. Hydrology and gully processes in the upper Araguaia River basin, Central Brazil. Z. Fur Geomorphol. Suppl. 2006, 145, 119-145.

77. Amare, S.; Keesstra, S.; van der Ploeg, M.; Langendoen, E.; Steenhuis, T.; Tilahun, S. Causes and controlling factors of Valley bottom Gullies. Land 2019, 8, 141. [CrossRef]

78. Mamedov, A.; Levy, G.; Shainberg, I.; Letey, J. Wetting rate, sodicity, and soil texture effects on infiltration rate and runoff. Soil Res. 2001, 39, 1293-1305. [CrossRef]

79. Dunaway, D.; Swanson, S.R.; Wendel, J.; Clary, W. The effect of herbaceous plant communities and soil textures on particle erosion of alluvial streambanks. Geomorphology 1994, 9, 47-56. [CrossRef]

80. Shahrivar, A.; Christopher, T.B.S. The effects of soil physical characteristics on gully erosion development in Kohgiloyeh \& Boyer Ahmad province Iran. Adv. Environ. Biol. 2012, 6, 397-405.

81. Gutiérrez, Á.G.; Schnabel, S.; Contador, F.L. Gully erosion, land use and topographical thresholds during the last 60 years in a small rangeland catchment in SW Spain. Land Degrad. Dev. 2009, 20, 535-550. [CrossRef]

82. Gigović, L.; Pourghasemi, H.R.; Drobnjak, S.; Bai, S. Testing a new ensemble model based on SVM and random forest in forest fire susceptibility assessment and its mapping in Serbia's Tara National Park. Forests 2019, 10, 408. [CrossRef]

83. Wei, T.; Simko, V. R package "corrplot": Visualization of a Correlation Matrix (Version 0.84). 2017. Available online: https: / / github.com/taiyun/corrplot (accessed on 8 December 2020).

84. Arabameri, A.; Pradhan, B.; Rezaei, K.; Lee, C.W. Assessment of landslide susceptibility using statistical- and artificial intelligencebased FR-RF integrated model and multiresolution DEMs. Remote Sens. 2019, 11, 999. [CrossRef]

85. Jenks, G.F.; Caspall, F.C. Error on choroplethic maps: Definition, measurement, reduction. Ann. Assoc. Am. Geogr. 1971, 61, 217-244. [CrossRef]

86. Kornejady, A.; Pourghasemi, H.R.; Afzali, S.F. Presentation of RFFR new ensemble model for landslide susceptibility assessment in Iran. In Advances in Natural and Technological Hazards Research; Springer: Amsterdam, The Netherlands, 2019; Volume 50, pp. $123-143$.

87. Arabameri, A.; Rezaei, K.; Pourghasemi, H.R.; Lee, S.; Yamani, M. GIS-based gully erosion susceptibility mapping: A comparison among three data-driven models and AHP knowledge-based technique. Environ. Earth Sci. 2018, 77. [CrossRef]

88. Mohammady, M.; Pourghasemi, H.R.; Amiri, M. Land subsidence susceptibility assessment using random forest machine learning algorithm. Environ. Earth Sci. 2019, 78. [CrossRef]

89. Lawrence, R.L.; Wood, S.D.; Sheley, R.L. Mapping invasive plants using hyperspectral imagery and Breiman Cutler classifications (RandomForest). Remote Sens Environ. 2006, 100, 356-362. [CrossRef]

90. Rahmati, O.; Pourghasemi, H.R.; Melesse, A.M. Application of GIS-based data driven random forest and maximum entropy models for groundwater potential mapping: A case study at Mehran Region, Iran. Catena 2016, 137, 360-372. [CrossRef]

91. Breiman, L. Random forests. Mach. Learn. 2001, 45, 5-32. [CrossRef]

92. Lai, J.S.; Tsai, F. Improving GIS-based landslide susceptibility assessments with multi-temporal remote sensing and machine learning. Sensors 2019, 19, 3717. [CrossRef]

93. Fang, P.; Zhang, X.; Wei, P.; Wang, Y.; Zhang, H.; Liu, F.; Zhao, J. The Classification Performance and Mechanism of Machine Learning Algorithms in Winter Wheat Mapping Using Sentinel-2 10 m Resolution Imagery. Appl. Sci. 2020, 10, 5075. [CrossRef] 
94. Liaw, M.A. Package 'randomForest'; University of California, Berkeley: Berkeley, CA, USA, 2018.

95. Ghimire, B.; Rogan, J.; Galiano, V.R.; Panday, P.; Neeti, N. An evaluation of bagging, boosting, and random forests for land-cover classification in Cape Cod, Massachusetts, USA. GIScience Remote Sens. 2012, 49, 623-643. [CrossRef]

96. Han, H.; Guo, X.; Yu, H. Variable selection using mean decrease accuracy and mean decrease gini based on random forest. In Proceedings of the 2016 7th IEEE International Conference on Software Engineering and Service Science (ICSESS), Beijing, China, 26-28 August 2016; pp. 219-224.

97. Bradley, A.P. The use of the area under the ROC curve in the evaluation of machine learning algorithms. Pattern Recogn. 1997, 30, 1145-1159. [CrossRef]

98. O'brien, R.M. A caution regarding rules of thumb for variance inflation factors. Qual. Quant. 2007, 41, 673-690. [CrossRef]

99. Yitbarek, T.W.; Belliethathan, S.; Stringer, L.C. The onsite cost of gully erosion and cost-benefit of gully rehabilitation: A case study in Ethiopia. Land Degrad. Dev. 2012, 23, 157-166. [CrossRef]

100. Meliho, M.; Khattabi, A.; Mhammdi, N. A GIS-based approach for gully erosion susceptibility modelling using bivariate statistics methods in the Ourika watershed, Morocco. Environ. Earth Sci. 2018, 77. [CrossRef]

101. Rahmati, O.; Tahmasebipour, N.; Haghizadeh, A.; Pourghasemi, H.R.; Feizizadeh, B. Evaluating the influence of geoenvironmental factors on gully erosion in a semi-arid region of Iran: An integrated framework. Sci. Total Environ. 2017, 579, 913-927. [CrossRef]

102. Akgün, A.; Türk, N. Mapping erosion susceptibility by a multivariate statistical method: A case study from the Ayvalik region, NW Turkey. Comput. Geosci. 2011,37, 1515-1524. [CrossRef]

103. Bewket, W. Land cover dynamics since the 1950s in Chemoga watershed, Blue Nile basin, Ethiopia. Mt. Res. Dev. 2002, 22, 263-269. [CrossRef]

104. Gábris, G.; Kertész, Á.; Zámbó, L. Land use change and gully formation over the last 200 years in a hilly catchment. Catena 2003, 50, 151-164. [CrossRef]

105. Jha, P.; Mohapatra, K.P.; Dubey, S.K. Impact of land use on physico-chemical and hydrological properties of ustifluvent soils in riparian zone of river Yamuna, India. Agrofor. Syst. 2010, 80, 437-445. [CrossRef]

106. Liu, X.B.; Zhang, X.Y.; Wang, Y.X.; Sui, Y.Y.; Zhang, S.L.; Herbert, S.J.; Ding, G. Soil degradation: A problem threatening the sustainable development of agriculture in Northeast China. PlantSoil Environ. 2010, 56, 87-97. [CrossRef]

107. Spaargaren, O. Major soils of the world. In Proceedings of the International Soil Conference and Information Centre, Wageningen, The Netherlands, 12 March-6 April 2001; pp. 2-46.

108. Nyssen, J.; Moeyersons, J.; Deckers, J.; Haile, M.; Poesen, J. Vertic movements and the development of stone covers and gullies, Tigray Highlands, Ethiopia. Z. Fur Geomorphol. 2000, 44, 145-164.

109. Wang, Y.; Sun, D.; Wen, H.; Zhang, H.; Zhang, F. Comparison of Random Forest Model and Frequency Ratio Model for Landslide Susceptibility Mapping (LSM) in Yunyang County (Chongqing, China). Int. J. Environ. Res. Public Health 2020, $17,4206$. [CrossRef] [PubMed] 